\title{
ALGORITMO DE COLÔNIA DE FORMIGAS E REDES NEURAIS ARTIFICIAIS APLICADOS NA MONITORAÇÃO E DETECÇÃO DE FALHAS EM CENTRAIS NUCLEARES
}

GEAN RIBEIRO DOS SANTOS

Dissertação apresentada como parte dos requisitos para obtenção do Grau de Mestre em Ciências na Área de Tecnologia Nuclear - Reatores.

Orientadora: Dra Iraci Martinez Pereira

\section{São Paulo}

2016 


\section{AGRADECIMENTOS}

A Deus pela vida e saúde.

À Prof ${ }^{a}$ Dra. Iraci Martinez Pereira pela orientação e pela confiança depositada para a realização deste trabalho.

À Universidade de São Paulo e ao IPEN pela estrutura e profissionais que contribuíram muito para a minha formação.

À CAPES pelo suporte financeiro fornecido durante a realização deste trabalho.

A todos os meus professores e colegas do IPEN, que colaboraram direta ou indiretamente par a realização deste trabalho.

Aos meus pais, pelo amor e apoio incondicional.

Aos meus tios Josué Ribeiro e Geilsa Ribeiro pelo apoio durante a realização deste trabalho.

A Flávia Augusta da Costa pelo carinho, incentivo e apoio em todos os momentos durante a realização deste trabalho. 


\section{RESUMO}

Um desafio recorrente em processos produtivos é o desenvolvimento de sistemas de monitoração e diagnóstico. Esses sistemas ajudam na detecção de mudanças inesperadas e interrupções, prevenindo perdas e mitigando riscos. Redes Neurais Artificiais (RNA) têm sido largamente utilizadas na criação de sistemas de monitoração. Normalmente as RNA utilizadas para resolver este tipo de problema são criadas levando-se em conta apenas parâmetros como o número de entradas, saídas e quantidade de neurônios nas camadas escondidas. Assim, as redes resultantes geralmente possuem uma configuração onde há uma total conexão entre os neurônios de uma camada e os da camada seguinte, sem que haja melhorias em sua topologia. Este trabalho utiliza o algoritmo de Otimização por Colônia de Formigas (OCF) para criar redes neurais otimizadas. $\mathrm{O}$ algoritmo de busca OCF utiliza a técnica de retropropagação de erros para otimizar a topologia da rede neural sugerindo as melhores conexões entre os neurônios. A RNA resultante foi aplicada para monitorar variáveis do reator de pesquisas IEA-R1 do IPEN. Os resultados obtidos mostram que o algoritmo desenvolvido é capaz de melhorar o desempenho do modelo que estima o valor de variáveis do reator. Em testes com diferentes números de neurônios na camada escondida, utilizando como comparativos o erro quadrático médio, o erro absoluto médio e o coeficiente de correlação, o desempenho da RNA otimizada foi igual ou superior ao da tradicional. 


\begin{abstract}
A recurring challenge in production processes is the development of monitoring and diagnosis systems. Those systems help on detecting unexpected changes and interruptions, preventing losses and mitigating risks. Artificial Neural Networks (ANN) have been extensively used in creating monitoring systems. Usually the ANN used to solve this kind of problem are created by taking into account only parameters as the number of inputs, outputs, and number of neurons in the hidden layers. This way, the result networks are generally fully connected and have no improvements in its topology. This work uses an Ant Colony Optimization (ACO) algorithm to create a tuned neural networks. The ACO search algorithm uses Back Error Propagation (BP) to optimize the network topology by suggesting the best neuron connections. The outcome ANN was applied to monitoring the IEA-R1 research reactor at IPEN. The results show that the algorithm is able to improve the performance of the model which estimates the values of the reactor variables. In tests with different numbers of neurons in the hidden layer, using as comparison the mean squared error, the mean absolute error, and the correlation coefficient, the performance of the optimized ANN proved equal or better than the equivalent traditional neural networks.
\end{abstract}




\section{SUMÁRIO}

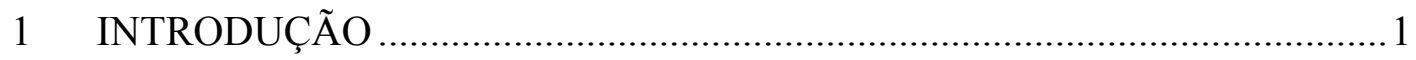

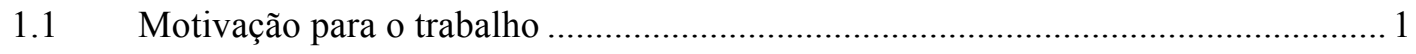

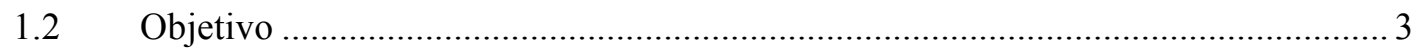

1.3 Aspectos relevantes e contribuições do trabalho .................................................... 3

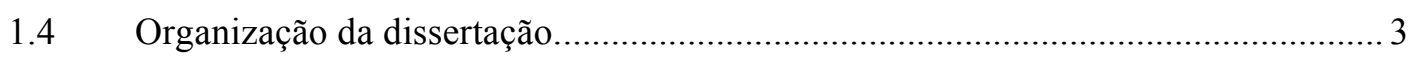

2 REVISÃO BIBLIOGRÁFICA ….............................................................. 5

3 MONITORAÇÃO DE REATORES NUCLEARES ...................................... 8

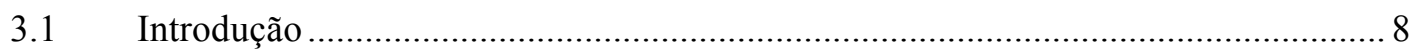

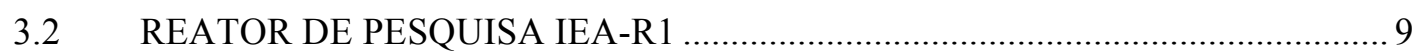

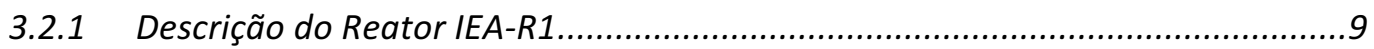

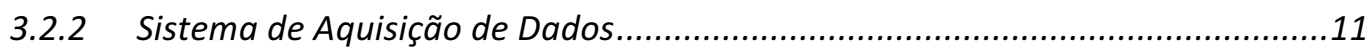

3.2.3 Balanço Térmico e Medida de Potência do Reator IEA-R1 ................................13

3.2.4 Instrumentos de Segurança ........................................................................

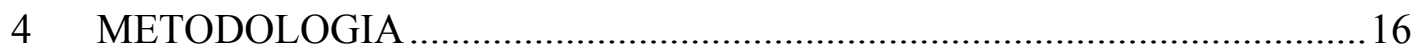

4.1 Otimização por Colônia de Formigas .................................................................... 16

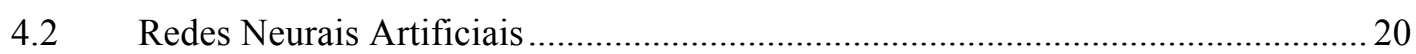

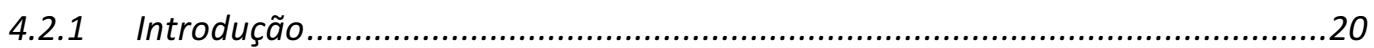

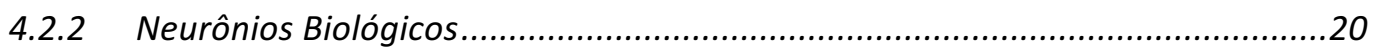

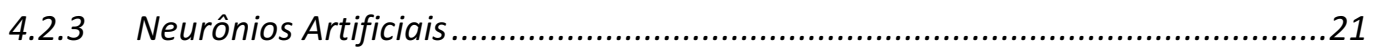

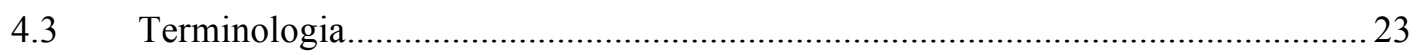

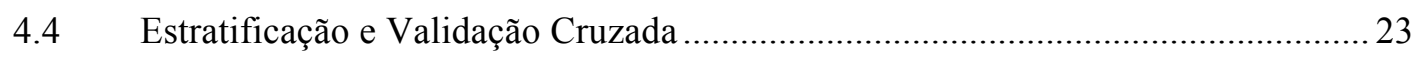

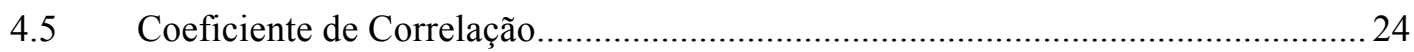

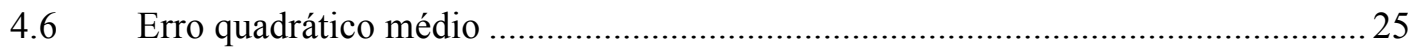

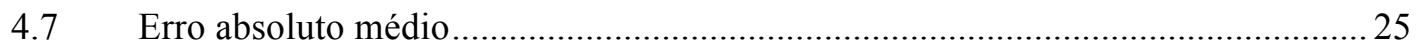

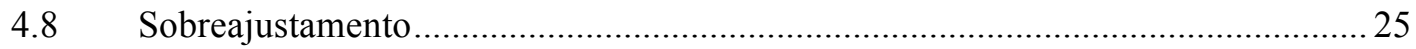

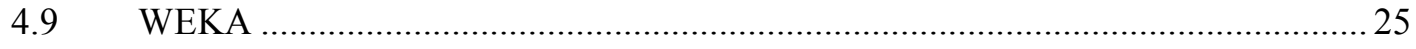

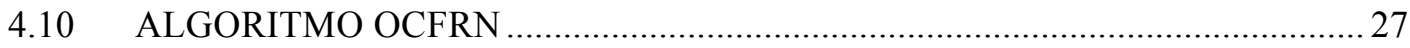

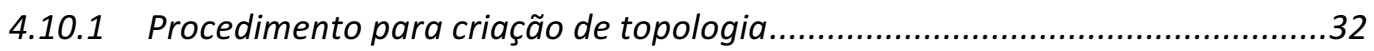

4.11 Programação do algoritmo OCFRN ………….................................................... 34

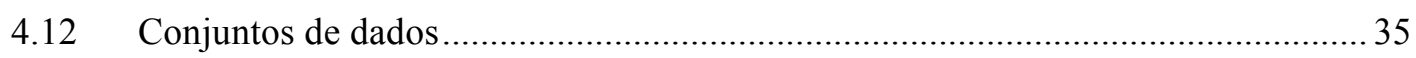

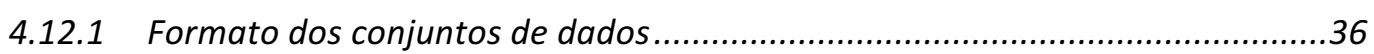

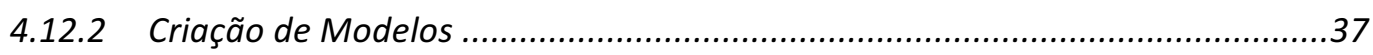

4.12.3 Treinamento das Redes Neurais Artificiais ....................................................38 


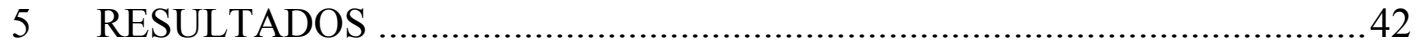

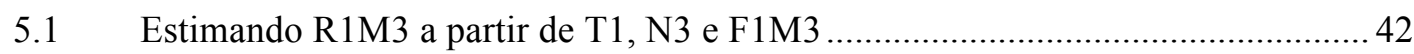

5.1.1 Testes com quatro neurônios na camada escondida .......................................42

5.1.2 Testes com cinco neurônios na camada escondida.............................................

5.1.3 Testes com seis neurônios na camada escondida ............................................47

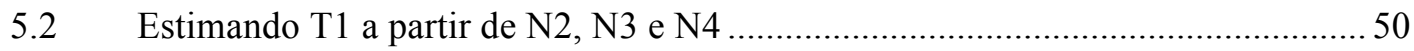

5.2.1 Testes com quatro neurônios na camada escondida ........................................50

5.2.2 Testes com cinco neurônios na camada escondida ..........................................52

5.2.3 Testes com seis neurônios na camada escondida ..............................................54

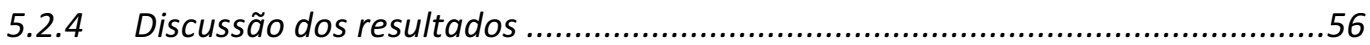

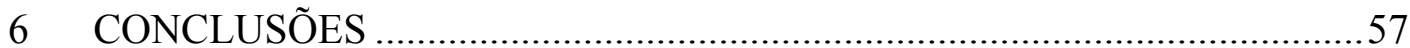

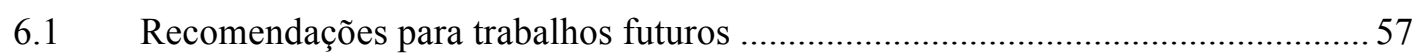

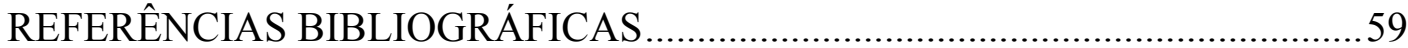




\section{LISTA DE TABELAS}

Tabela 1 - Variáveis do IEA-R1 monitoradas pelo SAD ...................................................... 11

Tabela 2 - Desempenho das RNA que estimam R1M3 com 4 neurônios na camada

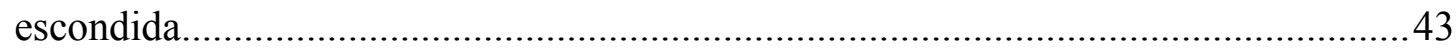

Tabela 3 - Desempenho das RNA que estimam R1M3 com 5 neurônios na camada

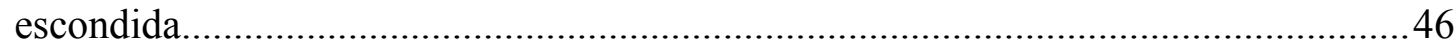

Tabela 4 - Desempenho das RNA que estimam R1M3 com 6 neurônios na camada

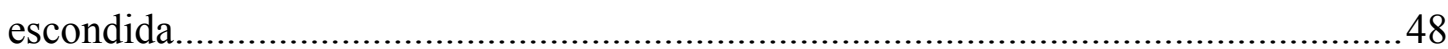

Tabela 5 - Desempenho das RNA que estimam T1 com 4 neurônios na camada escondida .50

Tabela 6 - Desempenho das RNA que estimam T1 com 5 neurônios na camada escondida 53

Tabela 7 - Desempenho das RNA que estimam T1 com 6 neurônios na camada escondida 


\section{LISTA DE FIGURAS}

Figura 1 - Estimando variáveis de reatores nucleares com técnicas de IA ......................... 8

Figura 2 - Diagrama esquemático do reator de pesquisas IEA-R1 do IPEN ....................... 10

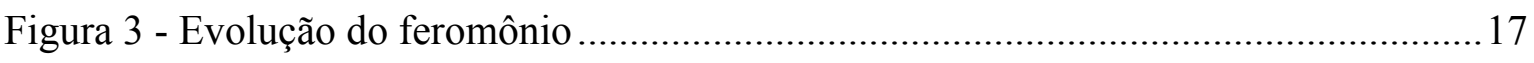

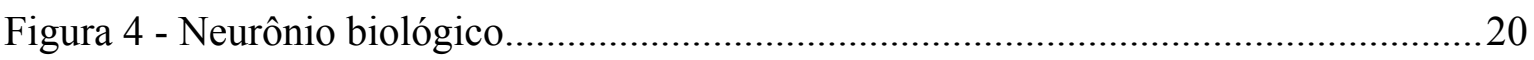

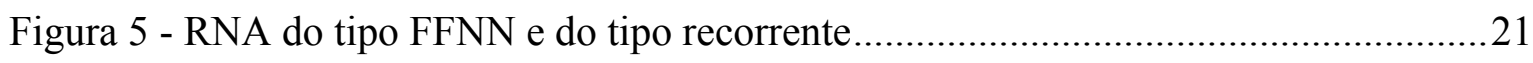

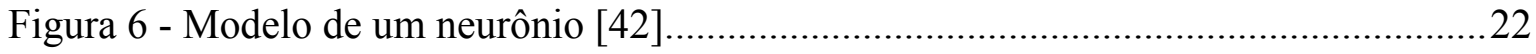

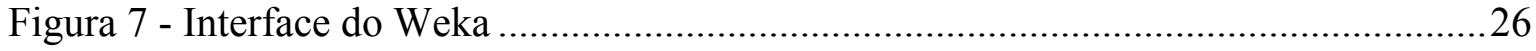

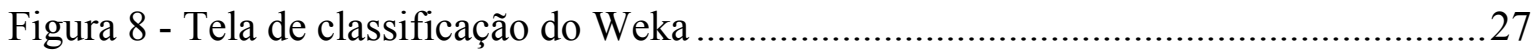

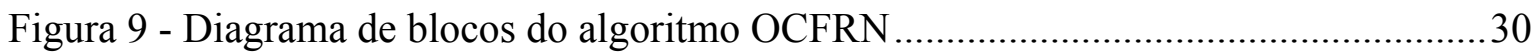

Figura 10 - Conexões entre neurônios da camada escondida no algoritmo OCFRN ...........31

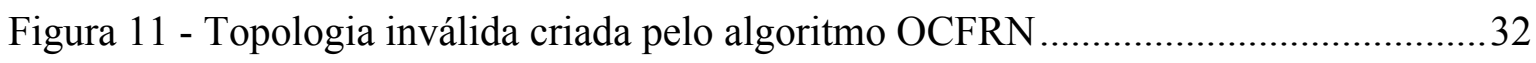

Figura 12 - Exemplo de um grafo de trilhas que podem ser seguidas ................................ 33

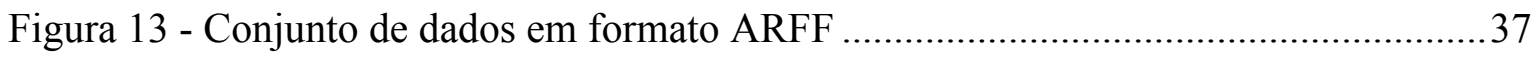

Figura 14 - Criação de modelo usando RNA no Weka .......................................................... 38

Figura 15 - Rede neural totalmente conectada com 4 neurônios na camada escondida .......39

Figura 16 - Rede neural totalmente conectada com 5 neurônios na camada escondida .......39

Figura 17 - Rede neural totalmente conectada com 6 neurônios na camada escondida .......40

Figura 18 - Rede neural otimizada com as variáveis T1, N3, F1M3 e R1M3 (configuração

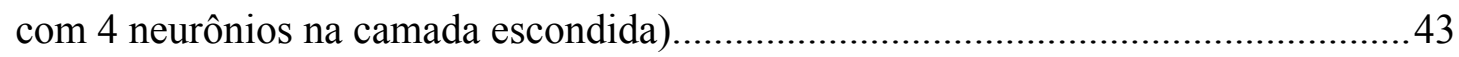

Figura 19 - Variável R1M3: saída desejada comparada com a saída obtida pela RNA totalmente conectada com 4 neurônios na camada escondida .....................................44

Figura 20 - Variável R1M3: saída desejada comparada com a saída obtida pela RNA otimizada com 4 neurônios na camada escondida ..........................................................4

Figura 21 - Rede neural otimizada com as variáveis T1, N3, F1M3 e R1M3 (configuração com 5 neurônios na camada escondida).

Figura 22 - Variável R1M3: saída desejada comparada com a saída obtida pela RNA totalmente conectada com 5 neurônios na camada escondida..... 46

Figura 23 - Variável R1M3: saída desejada comparada com a saída obtida pela RNA otimizada com 5 neurônios na camada escondida 47

Figura 24 - Rede neural otimizada com as variáveis T1, N3, F1M3 e R1M3 (configuração com 6 neurônios na camada escondida). 
Figura 25 - Variável R1M3: saída desejada comparada com a saída obtida pela RNA totalmente conectada com 6 neurônios na camada escondida

Figura 26 - Variável R1M3: saída desejada comparada com a saída obtida pela RNA otimizada com 6 neurônios na camada escondida

Figura 27 - Rede neural otimizada com as variáveis N2, N3, N4 e T1 (configuração com 4 neurônios na camada escondida) 50

Figura 28 - Variável T1: saída desejada comparada com a saída obtida pela RNA totalmente conectada com 4 neurônios na camada escondida

Figura 29 - Variável T1: saída desejada comparada com a saída obtida pela RNA otimizada com 4 neurônios na camada escondida.....

Figura 30 - Rede neural otimizada com as variáveis N2, N3, N4 e T1 (configuração com 5 neurônios na camada escondida) 52

Figura 31 - Variável T1: saída desejada comparada com a saída obtida pela RNA totalmente conectada com 5 neurônios na camada escondida .53

Figura 32 - Variável T1: saída desejada comparada com a saída obtida pela RNA otimizada com 5 neurônios na camada escondida

Figura 33 - Rede neural otimizada com as variáveis N2, N3, N4 e T1 (configuração com 6 neurônios na camada escondida) 54

Figura 34 - Variável T1: saída desejada comparada com a saída obtida pela RNA totalmente conectada com 6 neurônios na camada escondida. .55

Figura 35 - Variável T1: saída desejada comparada com a saída obtida pela RNA otimizada com 6 neurônios na camada escondida. 55 


\section{INTRODUÇÃO}

\subsection{Motivação para o trabalho}

A utilização de sensores tem se mostrado indispensável em diversas áreas do setor produtivo como a automação de indústrias de processo e manufatura, a robótica, a engenharia experimental, a indústria energética, etc [1]. Esses elementos servem para medir grandezas físicas e monitorar falhas. Quando há mudança em um dos valores lidos por um sensor, atuadores podem ser acionados de forma a controlar o sistema.

A necessidade de se ter qualidade, confiança e segurança nos processos produtivos tem estimulado pesquisas na área de monitoração e diagnóstico de falhas [2]. Nesse contexto, o sistema de medidas com sensores é de grande importância pois fornece dados para a operação manual e automática. Contudo, para que o controle do processo ocorra sem problemas é necessária a validação da informação recebida dos sensores. Isso aumenta a segurança e a disponibilidade do sistema.

Tanto em sistemas de malha aberta quanto em sistemas de malha fechada, falhas em sensores podem impactar o desempenho do sistema. $\mathrm{O}$ efeito dessas falhas depende do estágio em que são descobertas e vão desde a diminuição da disponibilidade até grandes perdas econômicas a impactos físicos a pessoas e instalações. Objetivando mitigar esses riscos, torna-se necessário implementar sistemas de controle tolerantes a falhas e confiáveis.

Tecnologias de detecção de falhas devem prover resposta rápida. Contudo, os usuários do sistema esperam que este não tenha perda de desempenho durante momentos de operação normal. Esses dois aspectos são conflitantes pois um sistema capaz de responder rapidamente a falhas deve necessariamente ser sensível a efeitos de alta frequência e isso, por sua vez, aumenta a sensibilidade do sistema a ruídos e alarmes falsos [3].

Com o objetivo de minimizar problemas de falhas em sensores, os sistemas de monitoração utilizam redundância. Tradicionalmente, essa redundância é criada fisicamente (também descrita como redundância por hardware) através de uma técnica que utiliza dois ou mais sensores na leitura de um mesmo parâmetro. Isso permite a identificação de um componente falho. Contudo, essa técnica só pode ser aplicada em sistemas onde haja espaço para a instalação de sensores redundantes. Além disso, instalar múltiplos sensores de monitoração aumenta os custos do projeto [4] [5]. 
Técnicas alternativas foram desenvolvidas para superar as desvantagens da redundância física. No início da década de 1970 foi introduzido o conceito de redundância analítica, que veio complementar a redundância por hardware. Este novo conceito se baseia no conhecimento do modelo matemático do sistema em questão, bem como os sinais de entrada e saída do sistema. Diferentes abordagens da redundância analítica foram propostas e validadas nas últimas décadas e isso trouxe como resultado o aumento da confiança nesses métodos e sua aplicação em sistemas reais [5].

A redundância analítica (também conhecida como redundância por software) faz predições de sinais através de um modelo do sistema. $\mathrm{O}$ modelo pode ser construído a partir das equações matemáticas que descrevem o fenômeno real ou a partir dos dados. As predições são então comparadas com os valores reais dos sensores do sistema [4] [6]. As vantagens da redundância analítica juntamente como os avanços na computação, aumentaram o uso de sistemas de monitoração baseados nessa nova técnica [4].

Diagnosticar falhas em sistemas pode ser considerado um problema de classificação que deve definir os dados como normais ou como falhos [7]. Assim, é possível inferir que todos os métodos de classificação poderiam ser utilizados nesse contexto. Contudo, é desafiador diagnosticar falhas em sistemas complexos e de larga escala pois nesses é grande a quantidade de ruído nos dados monitorados. Quando são consideradas todas as variáveis, grandes quantidades de dados reduzem o desempenho do diagnóstico do processo, pois ocorrem distúrbios causados por muitas variáveis irrelevantes [7].

Os procedimentos baseados em redundância analítica se dividem em dois grupos: os que são baseados no modelo matemático e os que são obtidos por procedimentos de Inteligência Artificial (IA). Dentro do grupo de IA, uma das técnicas utilizadas é a de Redes Neurais Artificiais (RNA) [4] [5]. As RNA são um modelo matemático para paradigmas computacionais com uma estrutura e funcionamento que se assemelha ao do cérebro de mamíferos [8].

Tradicionalmente, quando se cria um modelo capaz de estimar valores em problemas de regressão e classificação usando-se as redes neurais artificiais, são levados em conta apenas parâmetros como o número de entradas, saídas e camadas escondidas. Isso leva à criação de redes em cujo grafo se observa uma total conexão entre os nós de uma camada com os nós da camada seguinte, sem que haja otimização de topologia.

Existem várias técnicas de Inteligência Artificial além das RNA, dentre as quais podem ser citadas as Redes Bayesianas, as Máquinas de Vetores de Suporte, as Árvores de Decisão, a Lógica Nebulosa, os Algoritmos Genéticos (AG) e a Otimização por Colônia de 
Formigas (OCF) [9]. Embora essas técnicas sejam métodos computacionais autônomos, algumas delas podem se complementar [10]. Por exemplo: a Lógica Nebulosa pode ser utilizada para melhorar o desempenho da Otimização por Colônia de Formigas [11]; os Algoritmos Genéticos podem ser utilizados para otimizar RNA [10].

\subsection{Objetivo}

Este trabalho tem como objetivo utilizar o algoritmo de Otimização por Colônia de Formigas (OCF), que tem sido usado na resolução de problemas NP-complexos ${ }^{1}$ [12], para otimizar a topologia de redes neurais artificiais. Formigas artificiais são usadas para encontrar as melhores conexões entre neurônios de diferentes camadas de forma que o modelo resultante tenha um melhor desempenho. O algoritmo de busca baseado na OCF, que foi chamado de OCFRN, usa a técnica de retropropagação para otimizar a topologia da rede neural sugerindo as melhores conexões. A RNA otimizada possui uma capacidade de regressão melhor e produz melhores estimativas que a rede não otimizada. $\mathrm{O}$ modelo resultante foi aplicado para estimar o valor de variáveis do reator de pesquisas IEA-R1 do IPEN/CNEN-SP, possibilitando a obtenção de melhores diagnósticos.

\subsection{Aspectos relevantes e contribuições do trabalho}

As principais contribuições deste trabalho são:

- Proposta de aplicação do algoritmo de Otimização por Colônia de Formigas para otimizar a topologia de Redes Neurais Artificiais. Criação, utilizando o algoritmo de inteligência artificial desenvolvido, de um sistema de monitoração aplicado ao reator de pesquisas IEA-R1.

- Produzir um modelo otimizado, baseado em RNA, para estimar variáveis do reator IEA-R1, possibilitando um melhor diagnóstico de falhas.

- Produzir um método otimizado de treinamento de RNA que pode ser utilizado para criar modelos para monitorar variáveis de centrais nucleares.

\subsection{Organização da dissertação.}

- Capítulo 1: Neste capítulo é feita uma introdução, situando o tema da dissertação e definindo os objetivos do trabalho.

${ }^{1}$ NP é o acrônimo em inglês para polinomial não determinístico (Non-deterministic Polinomial). Problemas NP-complexos são aqueles cuja solução não pode ser verificada em tempo polinomial. 
- Capítulo 2: Aborda aspectos históricos de diferentes técnicas utilizadas na monitoração de falhas. Além disso, descreve outros trabalhos que utilizaram redundância por software para monitorar variáveis do reator IEA-R1 bem como outras aplicações do algoritmo de Otimização por Colônia de Formigas.

- Capítulo 3: Descreve os principais aspectos do reator de pesquisas IEA-R1 e do Sistema de Aquisição de Dados.

- Capítulo 4: Metodologia: teoria sobre Otimização por Colônia de Formigas, Redes Neurais Artificias e o algoritmo desenvolvido neste trabalho.

- Capítulo 5: Apresenta os resultados obtidos.

- Capítulo 6: Apresenta as conclusões obtidas e recomendações para trabalhos futuros. 


\section{REVISÃO BIBLIOGRÁFICA}

A bibliografia revisada apresenta trabalhos realizados na área da monitoração e diagnóstico de falhas utilizando técnicas de Inteligência Artificial (IA). Além disso, também são incluídos trabalhos que combinaram diferentes técnicas de IA e trabalhos sobre aplicação de técnicas de IA à detecção de falhas no reator IEA-R1.

Quando se aplica inteligência artificial (IA) na redundância analítica, estimativas dos sinais são feitas a partir de um modelo do sistema. Este modelo é construído a partir de um conjunto de dados [4] [6]. As estimativas podem ser então comparadas com os valores reais dos sensores, dando ao sistema de monitoramento uma forma alternativa de saber o valor de uma variável. Diversas técnicas de IA têm sido utilizadas na detecção de falhas, dentre as quais podem ser citadas as Redes Neurais Artificiais [13], as Máquinas de Vetores de Suporte [14], as Redes Bayesianas [15] e as Árvores de Decisão [16].

Embora as diferentes técnicas de IA sejam métodos computacionais autônomos, alguns deles podem se complementar. Por exemplo, uma técnica pode exigir a utilização de parâmetros iniciais e, quando não houver regras claras para a seleção destes, uma outra técnica poderia ser utilizada para sugeri-los [10]. Essa combinação pode aumentar a taxa de sucesso no treinamento de modelos a partir de dados e também criar modelos que possuem um melhor desempenho em tarefas de classificação e regressão.

A ideia de combinar técnicas de inteligência artificial não é recente. Por exemplo, a combinação de Algoritmos Genéricos (AG) com Redes Neurais Artificiais aconteceu no final dos anos 80 e início dos anos 90 [10]. BISHOP (1993) [17] utilizou algoritmos genéticos para otimizar RNA treinadas para estimar qual combinação de pigmentos produziria uma determinada cor. Seus resultados mostraram que as RNA otimizadas obtiveram um desempenho melhor do que aquelas não otimizadas.

Koehn (1994) [10] utilizou a técnica de Algoritmos Genéticos (AG) para otimizar parâmetros de Redes Neurais Artificiais (RNA), incluindo os pesos iniciais e a taxa de aprendizado. Esse trabalho também utilizou AG para criar RNA com topologia otimizada. Os resultados mostraram que, para redes com até um determinado tamanho (número de neurônios), a metodologia desenvolvida possui um desempenho melhor do que o das redes neurais tradicionais na otimização de pesos iniciais. Com relação à otimização da arquitetura, os resultados com AG também se mostraram melhores do que em RNA 
tradicionais, embora com um custo computacional alto. $\mathrm{O}$ autor sugere que investir tempo computacional em treinamento da RNA tradicional produz melhores resultados do que investir em otimização da topologia por algoritmos genéticos.

Dorigo e Gambardella (1997) [18] utilizaram o algoritmo de Otimização por Colônia de Formigas (OCF) para encontrar soluções para o Problema do Caixeiro Viajante. Esse trabalho mostrou que as formigas artificiais são capazes de gerar boas (e frequentemente ótimas) soluções para problemas de otimização.

Gonçalves (2006) [19] desenvolveu um sistema de monitoração e detecção de falhas utilizando a metodologia Group Method of Data Handling (GMDH). O sistema desenvolvido foi aplicado na monitoração de variáveis de operação do reator de pesquisas IEA-R1. A autora utilizou 2 conjuntos de dados: um obtido através de um modelo teórico do reator e outro obtido a partir de informações de operação do reator durante algumas semanas.

Bueno (2006) [4] desenvolveu um sistema de monitoração e detecção de falhas em sensores do reator IEA-R1 utilizando Redes Neurais Artificiais. O trabalho envolveu três etapas: monitoração, detecção e diagnóstico de falhas. Esta última etapa envolveu o uso da Lógica Nebulosa. Vários modelos foram desenvolvidos, escolhendo diferentes grupos de variáveis de entrada.

Ginidi, Kamel e Dorrah (2010) [11] utilizaram a Lógica Nebulosa para melhorar o desempenho do algoritmo de Otimização por Colônia de Formigas. O algoritmo proposto leva em consideração incertezas que podem ser encontradas em alguns parâmetros da OCF, como a função heurística e a quantidade de feromônio. O método foi testado no Problema Quadrático de Alocação e no Problema do Caixeiro Viajante. Os resultados indicaram que o método produz resultados melhores e com um melhor desempenho do que a técnica de OCF clássica.

Bashiri e Geranmayeh (2011) [20] utilizaram a técnica de Algoritmos Genéticos para otimizar o desempenho de Redes Neurais Artificiais. O algoritmo de busca foi utilizado para escolher parâmetros ótimos de RNA e o desempenho das redes foi comparado utilizando o erro quadrático médio, o coeficiente de correlação e o tempo de treinamento.

Salama e Freitas (2013) [21] combinaram Otimização por Colônia de Formigas com Redes Bayesianas (RB). A primeira técnica foi utilizada para aprender a estrutura de conhecimento da segunda. As RB são uma técnica de classificação que representa o conhecimento e modela a dependência ou independência de variáveis através de raciocínio 
probabilístico. Os resultados mostraram que o método desenvolvido possui um desempenho significativamente melhor do que o produzido por algoritmos bem conhecidos, (incluindo o Naive-Bayes) em termos de estimativa correta.

Salama e Abdelbar (2014) [22] utilizaram o algoritmo de otimização por colônia de formigas (OCF) para otimizar topologias de Redes Neurais Artificiais (RNA). O trabalho comparou a taxa de acerto de classificação de RNA totalmente conectadas com o de RNA otimizadas. Os autores utilizaram nos testes 20 conjuntos de dados conhecidos, fornecidas pela Universidade da Califórnia. Os resultados mostraram que as RNA otimizadas obtiveram desempenho igual ou superior ao das RNA tradicionais em 15 dos 20 conjuntos de dados utilizadas.

O sistema de monitoração de falhas desenvolvido neste trabalho se diferencia de outros trabalhos por utilizar o algoritmo de Otimização por Colônia de Formigas para otimizar a topologia de Redes Neurais Artificiais. Diferentemente do trabalho de Salama e Abdelbar (2014) [22], que criou um modelo para trabalhar com um problema de classificação (definir a classe de instâncias de 20 conjuntos de dados), este trabalho se aplica a um problema de regressão: estimar o valor de variáveis monitoradas no reator de pesquisas IEA-R1. Além disso, enquanto o trabalho desses autores utiliza um número fixo de neurônios na camada escondida, neste trabalho foram feitos testes com diferentes números de neurônios. 


\section{MONITORAÇÃO DE REATORES NUCLEARES}

\subsection{Introdução}

Reatores nucleares são dispositivos onde ocorrem, de forma controlada, reações nucleares de fissão. São usados principalmente para a produção de energia elétrica e para pesquisas na área de física e engenharia. Quanto à finalidade a que se destinam, podem ser classificados em reatores de potência e reatores de pesquisa. Os reatores de potência têm como finalidade gerar energia elétrica. Os reatores de pesquisa, por sua vez, são usados como fonte de nêutrons para diversos propósitos, incluindo experimentos em física nuclear e produção de radioisótopos [23].

Tanto os reatores de potência quanto os reatores de pesquisa possuem sistemas de monitoração e diagnóstico de falhas. Esses sistemas auxiliam a operação do reator, monitorando continuamente diversas variáveis através da leitura de sensores. Contudo, para facilitar a detecção de falhas, um modelo matemático do sistema pode ser construído através de técnicas de inteligência artificial como, por exemplo, as redes neurais artificiais. Outras técnicas de IA podem ser combinadas às RNA para melhorar o seu desempenho, incluindo a otimização por colônia de formigas. O objetivo dessa combinação é produzir um modelo capaz de estimar melhor o valor das variáveis do sistema. A Figura 1 apresenta um diagrama que mostra a relação entre essas duas técnicas de IA com o sistema dos reatores nucleares e suas variáveis monitoradas. Comparando o valor estimado pelo modelo com o valor lido pelo sensor é possível detectar e diagnosticar falhas em sensores.

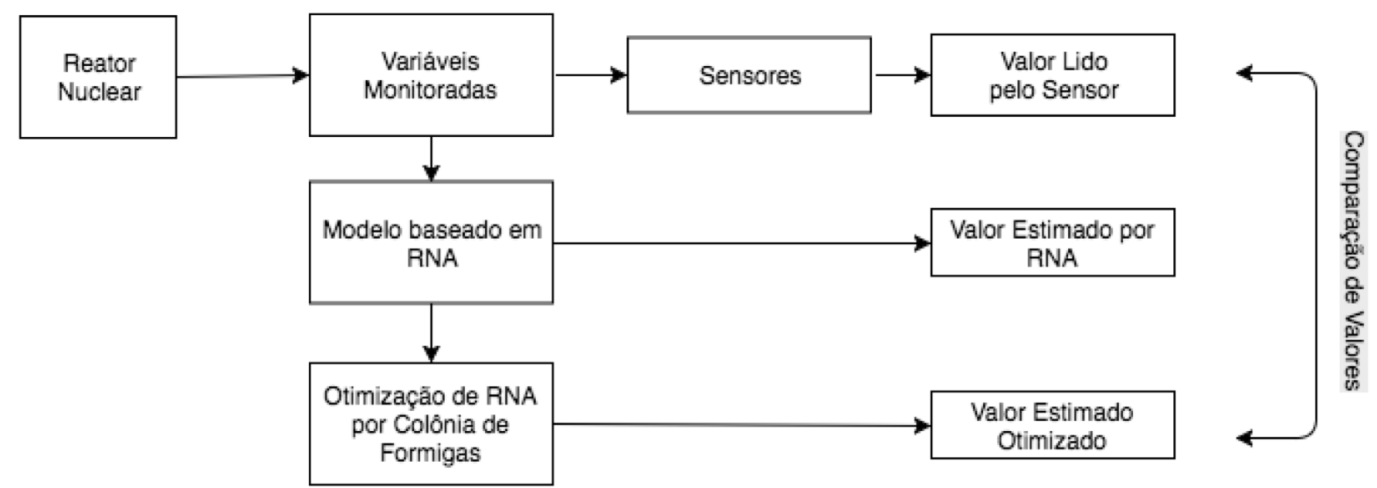

Figura 1 - Estimando variáveis de reatores nucleares com técnicas de IA 


\subsection{REATOR DE PESQUISA IEA-R1}

\subsubsection{Descrição do Reator IEA-R1}

O IEA-R1 é um reator de pesquisas do IPEN/CNEN-SP. É um reator do tipo piscina moderado e refrigerado a água. Construído pela empresa "Babcok \& Wilcox", ele usa grafite e berílio como refletores de nêutron. Sua primeira criticalidade aconteceu em 16 de setembro de 1957, quando passou a operar a 1 MW de potência. De 1960 a 1995, o reator operou a $2 \mathrm{MW}$, de segunda a sexta-feira, das 8:00h às 17:00h. O crescimento da demanda e novas aplicações de radioisótopos na área de medicina tornaram necessária a alteração do reator, que passou a operar a $5 \mathrm{MW}$ [24].

As finalidades do reator IEA-R1 são:

- Produção de radioisótopos para aplicações na medicina, indústria, agricultura e para pesquisas;

- Servir como uma fonte intensa de nêutrons em experimentos científicos de física nuclear, química, engenharia e biologia;

- Treinamento do corpo científico do IPEN-CNEN/SP em física de reatores, projetos, desenvolvimento de instrumentação nuclear e segurança de reatores;

- Treinamento e formação de operadores de reator;

- Análise radioquímica de amostras através do método de análise por ativação

A Figura 2 apresenta um diagrama de processo do reator de pesquisas IEA-R1. 


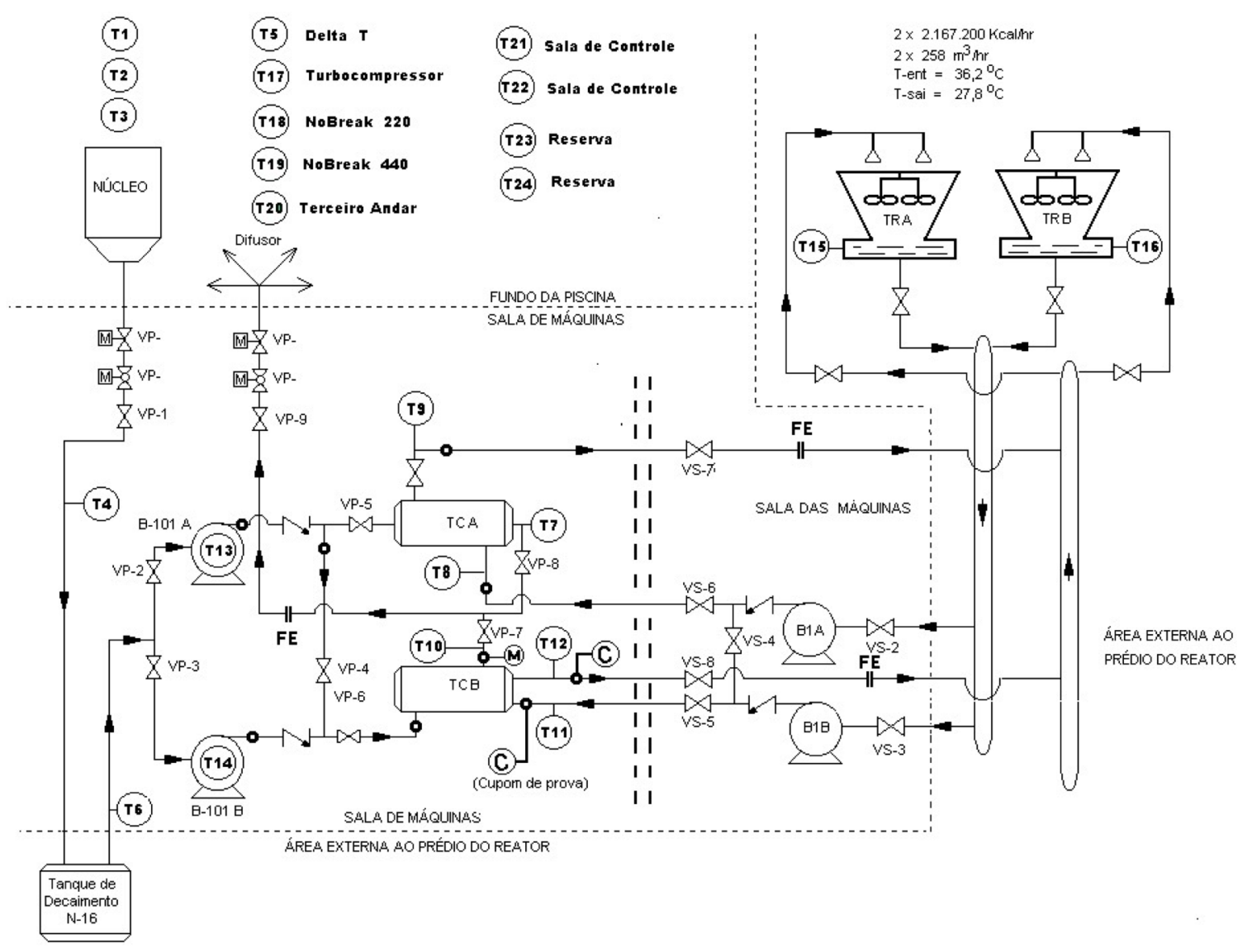

Figura 2 - Diagrama esquemático do reator de pesquisas IEA-R1 do IPEN

O prédio do reator IEA-R1 é composto por cinco pavimentos, distribuídos da seguinte forma [24]:

- Subsolo: onde se localiza a Casa das Máquinas;

- Primeiro andar: salão de experimentos;

- Segundo andar: sala de ventilação e ar-condicionado, almoxarifados e o acesso principal ao prédio;

- Terceiro andar: saguão da piscina do reator, Sala de Controle e oficinas de apoio;

- Quarto andar: sala de exaustão, com filtros e chaminé do sistema de exaustão do reator;

O núcleo do reator está localizado dentro da piscina, a 6,89 metros da superfície da água (da altura do ladrão à parte superior dos elementos combustíveis), e está montado em 
uma placa matriz com oitenta orifícios, na qual é possível a disposição dos combustíveis em vários arranjos experimentais. Esta placa é sustentada por uma treliça conectada a uma plataforma móvel, onde estão montados os quatro mecanismos de acionamento das barras e detectores que enviam sinais para a mesa de controle [24].

Oito tubos colimadores com diâmetros de 6 e 8 polegadas, um tubo tangencial à face sul do núcleo, estão dispostos radialmente ao núcleo do reator e são usados para experimentos com nêutrons. Outros dois tubos colimadores estão colocados na posição B de operação em frente à coluna térmica [24].

A piscina possui um volume de água de $272 \mathrm{~m}^{3}$, sendo dividida em dois compartimentos. $\mathrm{O}$ primeiro destina-se à estocagem, manuseio de material radioativo e elementos combustíveis, e o segundo contém o núcleo do reator e é destinado à operação. A piscina é revestida internamente por chapas de aço inoxidável, sendo que a blindagem radiológica que envolve o núcleo é feita por uma camada de água de 2 metros de espessura na região lateral, e até 2,4 metros de concreto com barita nas paredes da piscina [24].

\subsubsection{Sistema de Aquisição de Dados}

O reator IEA-R1 possui um sistema que monitora 58 variáveis operacionais. Esse sistema é chamado de Sistema de Aquisição de Dados (SAD) e as variáveis controladas incluem temperatura, vazão, nível, pressão, radiação, potência e posição das barras. O SAD mantém um histórico de todas as variáveis monitoradas e funciona de forma a não interferir com o controle do reator [25]. Na Tabela 1 a seguir tem-se as variáveis monitoradas pelo SAD.

Tabela 1 - Variáveis do IEA-R1 monitoradas pelo SAD.

\begin{tabular}{|l|l|}
\hline Z1 & Posição da barra de controle [0 a $1000 \mathrm{~mm}]$ \\
\hline Z2 & Posição da barra de segurança $1[0$ a $999 \mathrm{~mm}]$ \\
\hline Z3 & Posição da barra de segurança $2[0$ a $999 \mathrm{~mm}]$ \\
\hline Z4 & Posição da barra de segurança $3[0$ a $999 \mathrm{~mm}]$ \\
\hline PERIODO & Período [seg] \\
\hline N2 & Potência (canal de segurança 1) [\%] \\
\hline N3 & Potência (canal de segurança 2) [\%] \\
\hline N4 & Potência (canal de segurança 3) [\%] \\
\hline N5 & Potência logarítmica (canal log) [\%] \\
\hline
\end{tabular}




\begin{tabular}{|c|c|}
\hline N6 & Potência (canal linear) $[\%]$ \\
\hline N7 & Demanda (modo automático) [\%] \\
\hline N8 & Potência do N16 (canal N16) [\%] \\
\hline F1M3 & Vazão do primário [gpm] \\
\hline F2M3 & Vazão do secundário (trocador A) [gpm] \\
\hline F3M3 & Vazão do secundário (trocador B) [gpm] \\
\hline F23 & Vazão de água de emergência [gpm] \\
\hline DP & Delta P do núcleo [V] \\
\hline $\mathrm{C} 1$ & Condutividade da água da piscina após o tratamento [ $\mu \mathrm{mho}]$ \\
\hline $\mathrm{C} 2$ & $\begin{array}{l}\text { Condutividade da água da piscina antes da entrada no sistema de } \\
\text { retratamento }[\mu \mathrm{mho}]\end{array}$ \\
\hline L1 & Nível da piscina [\%] \\
\hline R1M3 & Taxa de dose na ponte de sustentação do núcleo, lado esquerdo [mR $/ \mathrm{h}]$ \\
\hline R2M3 & Taxa de dose na ponte de sustentação do núcleo, lado direito $[\mathrm{mR} / \mathrm{h}]$ \\
\hline R3M3 & Taxa de dose na parede do prédio do saguão da piscina, face norte $[\mathrm{mR} / \mathrm{h}]$ \\
\hline R4M3 & $\begin{array}{l}\text { Taxa de dose na parede da piscina, face sul, sobre o tubo de irradiação } \\
\mathrm{n}^{\circ} 8[\mathrm{mR} / \mathrm{h}\end{array}$ \\
\hline R5M3 & $\begin{array}{l}\text { Taxa de dose na parede da piscina, face oeste, sobre o tubo de irradiação } \\
n^{\circ} .3 \text { e } 4[\mathrm{mR} / \mathrm{h}]\end{array}$ \\
\hline R6M3 & $\begin{array}{l}\text { Taxa de dose na parede do prédio do reator, face leste, sobre os tubos de } \\
\text { armazenamento de material radioativo }[\mathrm{mR} / \mathrm{h}]\end{array}$ \\
\hline R7M3 & Taxa de dose no poço de coleta da piscina (poço SUMP) [mR/h] \\
\hline R8M3 & $\begin{array}{l}\text { Taxa de dose no sistema de retratamento de água - Coluna de resinas } \\
{[\mathrm{mR} / \mathrm{h}]}\end{array}$ \\
\hline R9M3 & Taxa de dose no trocador de calor $\mathrm{A}[\mathrm{mR} / \mathrm{h}]$ \\
\hline R10M3 & $\begin{array}{l}\text { Taxa de dose na parede ao fundo do porão, encostada ao duto de exaustão } \\
\text { entre os trocadores de calor A e B [cps] }\end{array}$ \\
\hline R11M3 & $\begin{array}{l}\text { Taxa de dose na sala do ar condicionado, junto ao duto de exaustão de ar } \\
\text { do primeiro andar [cps] }\end{array}$ \\
\hline R12M3 & Taxa de dose no saguão da piscina, junto ao duto de exaustão de ar [cps] \\
\hline R13M3 & Taxa de dose no duto de exaustão de ar da chaminé [cps] \\
\hline R14M3 & Taxa de dose no tanque de retenção [cps] \\
\hline T1 & Temperatura na superfície da piscina $\left[{ }^{\circ} \mathrm{C}\right]$ \\
\hline $\mathrm{T} 2$ & Temperatura à meia altura da piscina $\left[{ }^{\circ} \mathrm{C}\right]$ \\
\hline T3 & Temperatura sobre o núcleo do reator $\left[{ }^{\circ} \mathrm{C}\right]$ \\
\hline T4 & Temperatura na entrada do tanque de decaimento $\left[{ }^{\circ} \mathrm{C}\right]$ \\
\hline T5 & Diferença de temperatura $(\mathrm{T} 4-\mathrm{T} 3)\left[{ }^{\circ} \mathrm{C}\right]$ \\
\hline
\end{tabular}




\begin{tabular}{|l|l|}
\hline T6 & Temperatura no tanque de decaimento $\left[{ }^{\circ} \mathrm{C}\right]$ \\
\hline T7 & Temperatura na saída do primário (trocador A) $\left[{ }^{\circ} \mathrm{C}\right]$ \\
\hline T8 & Temperatura na entrada do secundário (trocador $\mathrm{A})\left[{ }^{\circ} \mathrm{C}\right]$ \\
\hline T9 & Temperatura na saída do secundário (trocador A) $\left[{ }^{\circ} \mathrm{C}\right]$ \\
\hline T10 & Temperatura na saída do primário (trocador B) $\left[{ }^{\circ} \mathrm{C}\right]$ \\
\hline T11 & Temperatura na entrada do secundário (trocador B) $\left[{ }^{\circ} \mathrm{C}\right]$ \\
\hline T12 & Temperatura na saída do secundário (trocador B) $\left[{ }^{\circ} \mathrm{C}\right]$ \\
\hline T13 & Temperatura na carcaça do motor da bomba B101-A $\left[{ }^{\circ} \mathrm{C}\right]$ \\
\hline T14 & Temperatura na carcaça do motor da bomba B102-A $\left[{ }^{\circ} \mathrm{C}\right]$ \\
\hline T15 & Temperatura externa na torre de refrigeração A $\left[{ }^{\circ} \mathrm{C}\right]$ \\
\hline T16 & Temperatura externa na torre de refrigeração B $\left[{ }^{\circ} \mathrm{C}\right]$ \\
\hline T17 & Temperatura na carcaça do motor do turbo compressor $\left[{ }^{\circ} \mathrm{C}\right]$ \\
\hline T18 & Temperatura no NO-BREAK $-220 \mathrm{~V}\left[{ }^{\circ} \mathrm{C}\right]$ \\
\hline T19 & Temperatura no NO-BREAK $-440 \mathrm{~V}\left[{ }^{\circ} \mathrm{C}\right]$ \\
\hline T20 & Temperatura ambiente $\left[{ }^{\circ} \mathrm{C}\right]$ \\
\hline T21 & Temperatura ambiente $\left[{ }^{\circ} \mathrm{C}\right]$ \\
\hline T22 & Temperatura ambiente $\left[{ }^{\circ} \mathrm{C}\right]$ \\
\hline T23 & Temperatura ambiente $\left[{ }^{\circ} \mathrm{C}\right]$ \\
\hline T24 & Temperatura ambiente $\left[{ }^{\circ} \mathrm{C}\right]$ \\
\hline
\end{tabular}

\subsubsection{Balanço Térmico e Medida de Potência do Reator IEA-R1}

A potência de um reator nuclear é diretamente proporcional à quantidade de nêutrons em seu núcleo. Assim, uma variação na população de nêutrons leva à mesma taxa de variação na potência do reator. Utilizando detectores de nêutrons é possível monitorar e registrar esta variação. O período $(\mathbf{T})$ de um reator é definido como o tempo necessário (em segundos) para que seu fluxo neutrônico seja multiplicado pelo fator "e", que equivale a 2,7182. [26].

No IEA-R1 há dois tipos de instrumentos que permitem monitorar o fluxo de nêutrons: instrumentos de controle e instrumentos de segurança. Juntos eles formam o subsistema de instrumentação nuclear, que é constituído por um canal de faixa ampla, três canais de segurança e um canal com mudança de escala. São utilizados 4 detectores de nêutrons, todos instalados na piscina do reator. Suas posições são ajustáveis de forma que 
forneçam um sinal de $100 \%$ quando o reator estiver operando a $5 \mathrm{MW}$ (sua potência nominal) [26].

A reatividade do IEA-R1, grandeza que descreve o desvio percentual da criticalidade do reator, é controlada por um sistema composto pelos seguintes elementos: um canal nuclear (denominado canal linear com mudança de escala); mecanismos de movimentação de barras de controle/segurança; dispositivos de acionamento manual e indicação de posição das barras; uma chave de seleção automático/manual; um potenciômetro de ajuste de demanda; uma unidade de controle automático. A potência térmica do reator pode ser medida por um canal de ${ }^{16} \mathrm{~N}$ cuja medida serve como referência para calibração dos demais canais nucleares [26].

O canal linear com mudança de escala é capaz de monitorar a potência do reator de $1 \mathrm{~mW}$ até $10 \mathrm{MW}$. Ele é formado por uma câmara de ionização compensada, uma fonte de alimentação e um picoamperímeto de multi-faixa linear. $\mathrm{O}$ picoamperímetro produz dois sinais, um para a unidade de controle automático do IEA-R1 e outro para aquisição de dados [26].

\subsubsection{Instrumentos de Segurança}

Quando necessário, o sistema de segurança e proteção do IEA-R1 atua interrompendo a corrente que alimenta os magnetos que sustentam as barras de controle/segurança (três barras de segurança e uma de controle). Essa ação faz com que as barras de controle/segurança sejam inseridas pela ação da gravidade e inicia o processo de desligamento do reator. A atuação é automática e ocorre quando uma das variáveis do sistema atinge um valor pré-definido [26].

A análise de segurança do IEA-R1 identifica situações em que o reator deve ser desligado. O sistema de proteção desse reator inclui todos os canais que monitoram os parâmetros relacionados com a segurança da sua instalação, os dispositivos de sinalização e alarme, e os dispositivos de acionamento manual [26].

Um dos parâmetros mais importantes relacionados à segurança de reatores nucleares é a taxa de dose. Dose é a quantidade total de radiação emitida e a taxa de dose é a maneira como esta dose é distribuída ao longo do tempo [27]. No IEA-R1, a variável R1M3 monitora a taxa de dose na ponte de sustentação do núcleo, lado esquerdo.

O IEA-R1 é um reator do tipo piscina. Esse é o tipo de reator de pesquisa mais utilizado no mundo e é frequentemente denominado reator do tipo MTR (sigla para Matetials Testing Reactor). A característica principal desse tipo de reator é o fato do seu 
núcleo estar imerso em uma piscina ou tanque contendo água. É um reator heterogêneo, pois nele o combustível nuclear e o moderador ficam separados fisicamente [23]. Nesse tipo de reator, a temperatura na superfície da piscina é uma variável importante no sistema de monitoração de segurança. No IEA-R1, a variável T1 é a responsável por monitorar essa temperatura. 


\section{METODOLOGIA}

As metodologias utilizadas neste trabalho foram:

- Otimização por Colônia de Formigas (OCF);

- Redes Neurais Artificiais (RNA);

A metodologia OCF foi utilizada para otimizar a topologia das RNA através da seleção das melhores conexões entre os neurônios. Estas técnicas são explicadas a seguir.

\subsection{Otimização por Colônia de Formigas}

No início da década de 1990 foi desenvolvido um método de resolução de problemas combinatórios complexos baseado em "formigas artificiais". Desde então, pesquisadores têm usado essa técnica com o objetivo de encontrar soluções para problemas classificados como NP-difíceis [28]. Por causa da sua inspiração em formigas reais, o algoritmo ficou conhecido como Otimização por Colônia de Formigas (OCF) e tem sido intensamente utilizado na resolução de problemas como o sequenciamento de tarefas (scheduling) [28], roteamento [29], roteirização [30] e otimização [31].

A OCF se baseia na capacidade das formigas de encontrar, através do uso do feromônio, um caminho otimizado de seu ninho para uma fonte de comida [32] [29]. O feromônio é uma substância química utilizada pelas formigas para marcar caminhos, de forma que os caminhos com maior concentração dessa substância tenham maior chance de serem seguidos [32] [33].

Uma das aplicações da heurística OCF é na resolução de problemas envolvendo minimização em grafos [34] [35]. Sua primeira utilização foi proposta por Marco Dorigo no Problema do Caixeiro Viajante (TSP - Traveling Salesman Problem) [36] [37], onde simulações de formigas construíam soluções para o TSP através da técnica conhecida como reforço positivo. Essa técnica se baseia na analogia com o comportamento de algumas espécies de formigas, que depositam feromônio nos caminhos até a fonte de alimento, permitindo assim o reforço dos caminhos mais trilhados (que podem ser ótimos) [28].

Os algoritmos baseados na OCF são criados com formigas artificiais, que são procedimentos probabilísticos baseados em feromônio artificial e heurística [38]. O feromônio é representado numericamente e é modificado a cada iteração, refletindo o processo de busca [38] [37]. A primeira técnica de busca baseada na OCF e que foi utilizada na resolução do TSP foi chamada de Ant System (AS) [37] [39]. O AS utiliza um 
grafo de representação onde cada aresta tem uma medida de feromônio, atualizada em tempo de execução pelas formigas artificiais [40]. Esse grafo é composto normalmente de duas informações numéricas: uma fixa (estabelecida na definição do problema) e outra variável [41] [37]. Essas duas informações são independentes entre si e estão relacionadas à conexão entre os pontos $j$ e $k$ do grafo. Distância entre nós e tempo para realização de operações são exemplos de informação fixa [41]. A cada iteração, as formigas adicionam componentes visando obter a solução do problema.

$\mathrm{Na}$ heurística do AS, cada caminho completo entre o início e o fim do grafo é oferecido como possível solução para o problema. Espalhando feromônio nas arestas, numa quantidade proporcional à qualidade da solução encontrada (relativamente às soluções obtidas por outras), as formigas escolhem os melhores caminhos. Através de dados probabilísticos, os insetos escolhem o próximo nó do grafo a ser visitado, baseado na heurística obtida pela distância entre os nós e a trilha de feromônio [34]. Para não ficar preso em uma solução mínima local, o algoritmo aplica a técnica de evaporação de feromônio, que faz com que esse elemento marcador se dissipe com o passar do tempo [31] [29].

Na Figura 3 são mostrados dois caminhos ligando um ninho de formigas a uma fonte de comida. Os níveis de feromônio (comprimentos das setas) são equilibrados no início do processo (Figura 3 a). Assim, a probabilidade de escolha de cada caminho é igual, fazendo com que um número equivalente de formigas passe pelos dois trechos. Contudo, os insetos que escolherem o maior caminho demoram mais para voltar, fazendo com que haja maior evaporação da substância química depositada. Então, a proporção da quantidade de feromônio no caminho mais longo diminui em relação àquela no caminho mais curto (Figura 3 b). Após algumas iterações, o caminho mais curto se sobressai (Figura 3 c) [28].

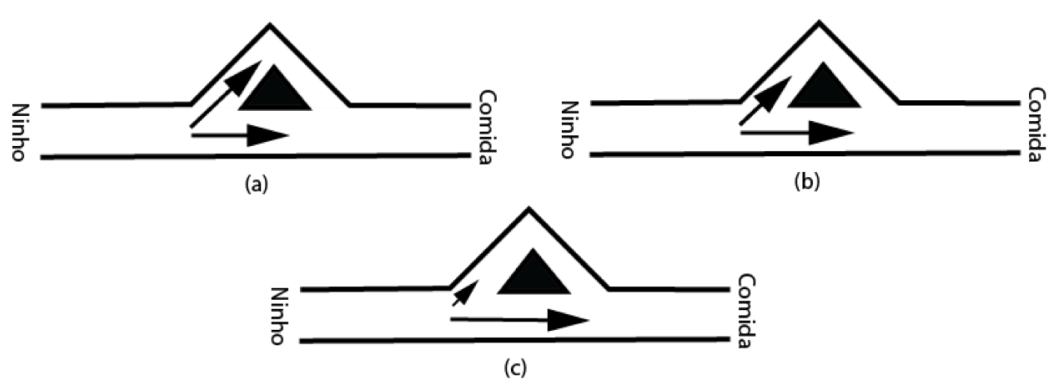

Figura 3 - Evolução do feromônio 
O Quadro 1 mostra o pseudocódigo da otimização por colônia de formigas.

Repita

Criar as formigas e posicioná-las;

Repita

Para cada formiga, faça

Aplicar a regra de transição de estado para construir uma solução

Atualizar feromônio localmente;

Fim para;

Até que todas as formigas tenham construído uma solução completa

Gerar o escalonamento associado a cada uma das formigas;

Atualizar o feromônio globalmente;

Guardar a melhor solução obtida até o momento;

Até que o critério de parada seja satisfeito;

Quadro 1 - Pseudocódigo da otimização por colônia de formigas [30].

No algoritmo AS, proposto por Dorigo [36], uma formiga $k$, dotada de uma memória $M_{k}$, que armazena os nós que já foram visitados, quando posicionada no nó $r$ do grafo, escolhe o próximo nó $u$ para visitar com uma distribuição probabilidade dada pela equação (1)

$$
s=\left\{\begin{array}{l}
\underset{u \nexists M_{k}}{\operatorname{argmax}}\left\{[\tau(r, u)]^{\alpha} \cdot[\eta(r, u)]^{\beta}\right\} \\
S \text { otherwise }
\end{array} \text { if } q \leq q_{0}\right.
$$

Na equação (1) $\tau(r, u)$ é a quantidade de feromônio na aresta que vai do nó $r$ ao nó $u ; \eta(r, u)$ é a função heurística (inverso da distância entre $r$ e $u$ ); $\alpha$ e $\beta$ são parâmetros que representam os pesos dados à inteligência global e à função heurística, respectivamente; $q$ é um valor escolhido aleatoriamente com probabilidade uniforme no intervalo $[0,1]$; $q_{0}$ é um parâmetro $\left(0 \leq \mathrm{q}_{0} \leq 1\right)$; $S$ é uma variável aleatória selecionada de acordo com a distribuição de probabilidade descrita na equação (2) [36]: 


$$
p_{k}(r, s)=\frac{[\tau(r, s)]^{\alpha} \cdot[\eta(r, s)]^{\beta}}{\sum_{u \nexists M_{k}}[\tau(r, u)]^{\alpha} \cdot[\eta(r, u)]^{\beta}}
$$

Na equação (2), $p_{k}(r, s)$ é a probabilidade da formiga $k$ escolher seguir a aresta que vai do nó $r$ ao nó $s . M_{k}$ é o conjunto de nós que já foram visitados pela formiga $k$.

Cada vez que uma aresta é selecionada por uma formiga, sua quantidade de feromônio é atualizada através de um processo chamado de atualização local. O propósito dessa atualização é evitar que uma aresta com uma grande quantidade de feromônio seja escolhida por todas as formigas [36]. A atualização local sugerida por Dorigo e Colorni é:

$$
\tau(r, s) \leftarrow(1-\rho) \cdot \tau(r, s)+\rho \cdot \tau_{0}
$$

onde $\tau_{0}$ e $\rho$ são parâmetros escolhidos pelo usuário.

No algoritmo AS, além da atualização local, há também a atualização global de feromônio cujo objetivo é destacar as arestas que fazem parte dos caminhos mais curtos. Quando todas as formigas tiverem encontrado uma solução para o problema, aquela que encontrou a melhor solução deposita feromônio nas arestas que compõe o caminho [30]. A quantidade de feromônio depositada é inversamente proporcional à distância da solução. A atualização global sugerida no algoritmo AS é:

$$
\tau(r, s) \leftarrow(1-\rho) . \tau(r, s)+\rho . \Delta \tau(r, s)
$$

Na equação (4) $\Delta \tau(r, s)$ é definido como $1 / L_{k}$ e $L_{k}$ é a distância do caminho mais curto encontrado na iteração atual.

A atualização global mostra que as formigas depositam em cada aresta da solução uma quantidade de feromônio inversamente proporcional à distância, isto é, quanto mais curto o caminho, maior a quantidade de feromônio depositado nas arestas. Esta atualização é similar à técnica conhecida como aprendizado por reforço, em que as melhores soluções são priorizadas.

Existem diversas vantagens de se utilizar a meta-heurística OCF. Uma delas é o fato de ser um paradigma autoadaptativo e capaz de executar tanto buscas locais quanto globais em um espaço amplo e dinâmico [29]. Além disso, devido à sua natureza paralelizável, essa técnica pode ser programada em unidades de processamento gráfico 
(GPU) [34] [35]. Outro ponto positivo da otimização por colônia de formigas é a boa escalabilidade e necessidade de pouca informação global sobre o estado do grafo [29].

\subsection{Redes Neurais Artificiais}

\subsubsection{Introdução}

As Redes Neurais Artificiais (RNA) são inspiradas nas redes neurais biológicas e são desenvolvidas para resolver problemas em áreas como tomada de decisão, categorização, aproximação de funções, otimização, predição e controle [42]. Elas podem ser descritas como sistemas de processamento distribuído e paralelo, formados de um número grande de processadores simples interconectados [42]. O tipo de RNA conhecido como redes neurais de propagação para frente (do inglês Feed Forward Neural Networks FFNN) é uma das técnicas mais aplicadas na classificação de padrões [22]. Normalmente as FFNN são construídas em uma topologia de 3 camadas: entradas, camada escondida e camada de saída. Nessa topologia geralmente cada neurônio em cada camada é conectado a todos os neurônios na camada seguinte [22].

\subsubsection{Neurônios Biológicos}

O neurônio é uma célula biológica especial com a capacidade de processar informação. Sua estrutura pode ser dividida em três seções: o corpo celular, os dendritos e o axônio, como mostra a Figura 4 [42].

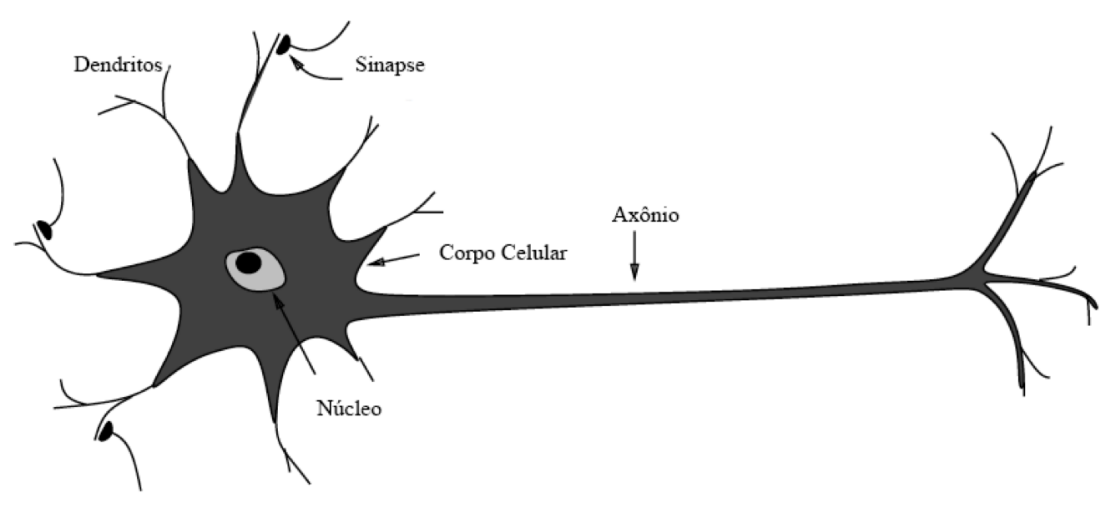

Figura 4 - Neurônio biológico

O corpo celular possui um núcleo contendo informação hereditária e um plasma contendo equipamento molecular usado na produção de material necessário ao neurônio. 
Um neurônio recebe impulsos de outros neurônios através dos dendritos e transmite sinais pelo axônio. $\mathrm{O}$ axônio pode se dividir em filamentos no fim dos quais se encontram as sinapses, que são o local de contato entre dois neurônios [42].

Substâncias químicas chamadas de neurotransmissores são liberadas quando um impulso atinge uma sinapse. O papel dos neurotransmissores é excitar ou inibir um neurônio, permitindo ou não a formação de impulsos nervosos no axônio de saída [42].

\subsubsection{Neurônios Artificiais}

Uma RNA é uma rede paralela de processamento de informações que relaciona um vetor de entradas a um vetor de saídas. Ela consiste de um número de neurônios artificiais que são interconectados por canais aos quais são associados pesos. A forma como os neurônios são interconectados determina a forma como o processamento acontece [43].

Uma forma de classificar as RNA é quanto à direção do fluxo de dados na rede. As redes onde a informação passa em um sentido são chamadas de redes de propagação para frente. Nesse tipo de rede a informação é recebida pelos nós da camada de entrada, que a processa e a passa para a camada seguinte (camada escondida). Podem ser criadas uma ou mais camadas escondidas, que também processam a informação e a passam para a camada seguinte (até que a camada de saída seja alcançada). As redes onde a informação flui em ambas as direções são chamadas de recorrentes [43]. Para ser classificada como recorrente, uma RNA deve ter pelo menos uma retroalimentação [44].

A Figura 5 ilustra uma RNA de propagação para frente (Figura 5 a) e uma RNA recorrente (Figura 5 b).

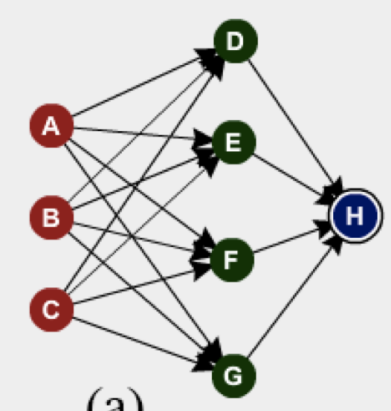

(a)

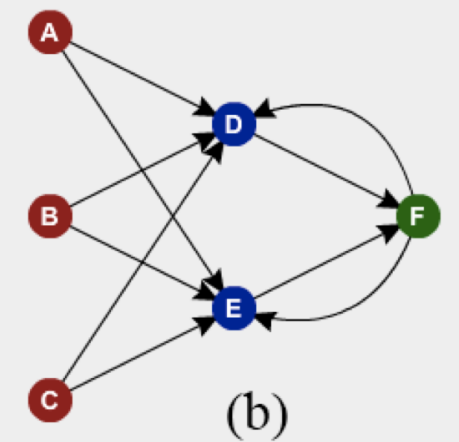

(b)

Figura 5 - RNA do tipo FFNN e do tipo recorrente 
Em uma rede neural com propagação para frente cada neurônio computa uma soma ponderada de seus $r$ sinais de entrada e gera uma saída $o_{i}$ dada por

$$
n e t_{i}=\sum_{i=1}^{r} w_{i j} o_{j}+b_{i}, o_{i}=f\left(n e t_{i}\right)=\frac{1}{1+e^{-n e t_{i}}}
$$

onde $w_{i j}$ é o peso da sinapse associada à conexão entre o neurônio $j$ e o neurônio $i$; $o_{j}$ é a saída de um neurônio na camada anterior; $b_{i}$ representa o auto-bias do neurônio; $f$ é uma função de ativação (que na equação foi mostrada como a função sigmoide) [22].

A Figura 6 mostra um diagrama esquemático do neurônio artificial. Esta entidade computa uma soma ponderada de suas $n$ entradas e gera uma saída "1" se esta soma é maior que um determinado limiar, ou “0”, caso contrário [42].

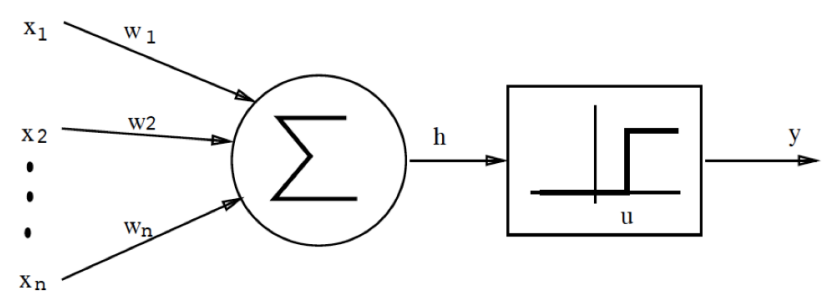

Figura 6 - Modelo de um neurônio [42]

Uma FFNN com $n$ entradas e $m$ saídas pode ser treinada com base em um conjunto de exemplos $\tau$. Cada exemplo $p$ no conjunto de treinamento é aplicado à camada de entrada e o sinal se propaga através das camadas escondidas até alcançar a camada de saída. Então, a saída da rede ( $y$ ') é comparada com a saída definida no conjunto de treinamento $(y)$ para se determinar o erro da rede $(E p)$ [36]. A função mais usada para calcular o erro é a soma dos erros quadráticos [22] [45]:

$$
E_{p}=\frac{1}{2} \sum_{i=1}^{m}\left(y-y^{\prime}\right)^{2}
$$

O treinamento de uma rede neural de topologia fixa pode ser tratado como o problema de minimização de uma função multidimensional. Isso se deve ao fato de que, embora o erro da rede dependa do conjunto de treinamento, da topologia, dos pesos e dos bias, se mantivermos os dois primeiros fixos, a função de erro dependerá apenas dos pesos 
e bias. Assim, treinar uma rede neural torna-se o problema de minimizar uma função matemática [22].

Um dos algoritmos de treinamento mais usados em redes neurais é o da retropropagação (BP backpropagation) de erros baseado no gradiente descendente. Quando se usa essa técnica, a derivada do vetor $(E)$ é calculada com relação a cada componente do vetor $w$ (o vetor de pesos). Essa derivada é chamada de gradiente de $E$ com relação a $w$ [46].

Como o gradiente especifica a direção do aumento mais acentuado de $E$, a regra de treinamento para o gradiente descendente é:

$w \leftarrow w+\Delta w$

onde

$\Delta w=-\eta \nabla E(w)$

Na equação (8) $\eta$ é um número positivo chamado de taxa de aprendizado e determina o tamanho do passo na busca do gradiente descendente [46].

Como o algoritmo de retropropagação é largamente utilizado, muitas variantes dele foram criadas. Uma alteração comum é alterar a regra de atualização de pesos da equação (8) fazendo com que o incremento na iteração $n$ dependa parcialmente da atualização ocorrida na iteração $n-1$, conforme a equação a seguir [46]:

$$
\Delta w(n)=-\eta \nabla E(w)+\alpha \Delta w(n-1)
$$

$\mathrm{Na}$ equação (9) $\Delta w(n)$ representa a atualização de pesos realizada na iteração $n$ e $0 \leq a<1$ é uma constante chamada de momentum.

\subsection{Terminologia}

Neste trabalho foi utilizada a seguinte terminologia: cada um dos registros utilizados por um algoritmo de IA para criar um modelo foi definido como "instância"; cada um dos valores de uma instância foi chamado de "atributo" [46]. Comparando um conjunto de dados com uma tabela, as linhas seriam as instâncias e as colunas seriam os atributos.

\subsection{Estratificação e Validação Cruzada}

Uma prática comum ao se realizar modelagens utilizando métodos de inteligência artificial é reservar uma certa quantidade de dados para testes e usar o restante para treinamento. É comum se usar um terço das instâncias para testes e dois terços para 
treinamento [45]. Contudo, um desses dois grupos em que os dados foram separados pode não ser representativo em relação ao todo. Embora não seja possível afirmar se uma amostra é de fato representativa ou não, pode-se ao menos garantir que cada classe presente no conjunto de dados esteja representada na amostra em proporção similar à do conjunto todo. A falta de exemplos de determinada classe no conjunto de treinamento provavelmente criaria um modelo incapaz de classificar corretamente instâncias dessa classe. O procedimento que faz essa análise de representatividade das amostras é chamado de estratificação [45].

Uma outra forma de minimizar problemas de viés na construção de modelos de classificação a partir de conjuntos de treinamento é repetir o processo de treinamento e teste várias vezes, com amostras aleatórias. Na técnica conhecida como validação cruzada de $k$ partições, um conjunto de dados $D$ é dividido aleatoriamente em $k$ subconjuntos mutuamente exclusivos (as partições), todos aproximadamente do mesmo tamanho [47]. Durante o treinamento, cada repetição utiliza uma parte dos dados para treinamento e outra para testes (pode-se fazer estratificação das amostras). O erro geral é então definido como uma média dos erros de cada iteração [45].

A validação cruzada com 10 partições é uma técnica estatística e é a forma padrão de estimar a taxa de erro de um algoritmo de aprendizado, dado um conjunto fixo de dados. É comum, ao dividir os dados em 10 partes, aplicar o método de estratificação pois alguns testes têm mostrado que isso melhora um pouco o resultado. $\mathrm{O}$ número 10 como quantidade sugerida de partições surgiu após extensivos testes em vários conjuntos de dados, com diferentes técnicas de aprendizado, além de algumas evidências teóricas [45].

\subsection{Coeficiente de Correlação}

O coeficiente de correlação é uma grandeza estatística que mede o quão bem a variação de um valor $p$, estimado por um modelo, é explicada pelo valor real $a$ das instâncias [20]. Ou seja, ele mede a correlação entre os valores reais de instâncias $(a)$ e os valores previstos por um modelo $(p)$. Seu cálculo é obtido pela seguinte equação [45]:

Coeficiente de correlação $=\frac{S_{P A}}{\sqrt{S_{P S_{A}}}}$

onde

$$
\begin{aligned}
& S_{P A}=\frac{\sum_{i}\left(p_{i}-\bar{p}\right)\left(a_{i}-\bar{a}\right)}{n-1} \\
& S_{P}=\frac{\sum_{i}\left(p_{i}-\bar{p}\right)^{2}}{n-1}
\end{aligned}
$$




$$
S_{A}=\frac{\sum_{i}\left(a_{i}-\bar{a}\right)^{2}}{n-1}
$$

\subsection{Erro quadrático médio}

O erro quadrático médio calcula a média dos quadrados das diferenças entre o valor estimado e o valor real de uma variável. Quando aplicada na criação de modelos a partir de técnicas de inteligência artificial, essa grandeza pode ser calculada como [45]:

$$
\text { Erro quadrático médio }=\frac{\left(p_{1}-a_{1}\right)^{2}+\cdots+\left(p_{n}-a_{n}\right)^{2}}{n}
$$

\subsection{Erro absoluto médio}

Em estatística, o erro absoluto médio calcula a média das diferenças entre o valor real e o valor medido de uma variável. Quando aplicado na criação de modelos a partir de técnicas de inteligência artificial, essa grandeza pode ser calculada como [45]:

$$
\text { Erro absoluto médio }=\frac{\left|p_{1}-a_{1}\right|+\cdots+\left|p_{n}-a_{n}\right|}{n}
$$

\subsection{Sobreajustamento}

Um objetivo comum ao se trabalhar com técnicas de Inteligência Artificial é criar modelos com boa capacidade de generalização, ou seja, modelos capazes de classificar corretamente novos exemplos que não faziam parte do conjunto de treinamento. Quando o modelo criado apresenta um bom desempenho de classificação no conjunto de treinamento e um desempenho ruim em dados novos e desconhecidos, ele é considerado sobreajustado (do inglês overfit) [22].

\subsection{WEKA}

O Weka é um programa que inclui uma coleção de algoritmos de aprendizado de máquina e ferramentas de pré-processamento de dados. Ele permite testar modelos, de forma rápida e fácil, em diferentes conjuntos de dados. Suas ferramentas de préprocessamento permitem preparar os dados, trabalhando com atributos ou instâncias e incluem: normalização, seleção de atributo-classe, combinação de atributos, etc. Dentre os algoritmos de aprendizado de máquina incluídos nessa ferramenta, encontram-se: árvore de decisão, redes bayesianas, máquina de vetores de suporte, redes neurais, etc [45]. A Figura 7 mostra a tela principal da interface gráfica do Weka. 


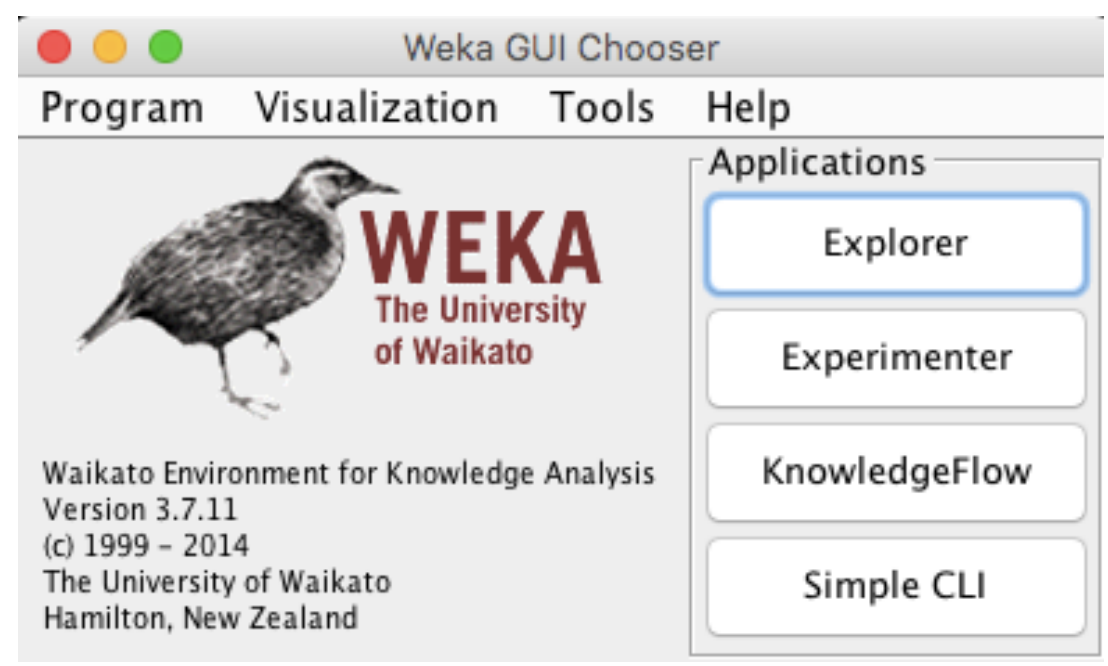

Figura 7 - Interface do Weka

Desenvolvido na Universidade de Waitako, na Nova Zelândia, o Weka foi escrito na linguagem Java, é distribuído sob os termos da licença GNU General Public License e pode ser descarregado a partir do endereço http://www.cs.waikato.ac.nz/ml/weka/. O nome significa Waitako Environment for Knowledge Analysys. Ele pode ser executado em diferentes sistemas operacionais, incluindo Linux, Windows e Macintosh. Através de uma interface gráfica o usuário pode testar e comparar diferentes técnicas de aprendizado de máquina e identificar a mais apropriada para se trabalhar com um problema específico [45].

O Weka inclui ferramentas para se trabalhar com os principais problemas de mineração de dados, incluindo: regressão, classificação, agrupamento e seleção de atributo. Seus dados de entrada são fornecidos através de uma tabela relacional cujo conteúdo pode ser lido de um arquivo ou gerado por uma consulta a uma base de dados. Ao estimar os melhores parâmetros para os modelos, o sistema permite que sejam utilizadas técnicas estatísticas que reduzem problemas de sobreajustamento. Uma dessas técnicas é chamada de validação cruzada com 10 partições e permite que seja escolhido um número $n$ de partições (folds) em que o conjunto de dados será dividido. Os dados são então separados em $n$ partições aproximadamente iguais e cada uma delas é utilizada exatamente uma vez para testes num modelo onde as demais foram utilizadas para treinamento. $\mathrm{O}$ método padrão usado na precisão da taxa de erro de um algoritmo de aprendizado é usar validação cruzada com 10 partições estratificadas (o termo em inglês é stratified tenfold crossvalidation) [45]. Nos experimentos realizados neste projeto, foi utilizado esse método. A 
Figura 8 apresenta a tela de classificação do Weka. Nela está selecionado o classificador baseado em Redes Neurais Artificiais (que aparece na figura como "Multilayer Perceptron"). A figura também mostra as opções de teste e os resultados da execução do algoritmo.

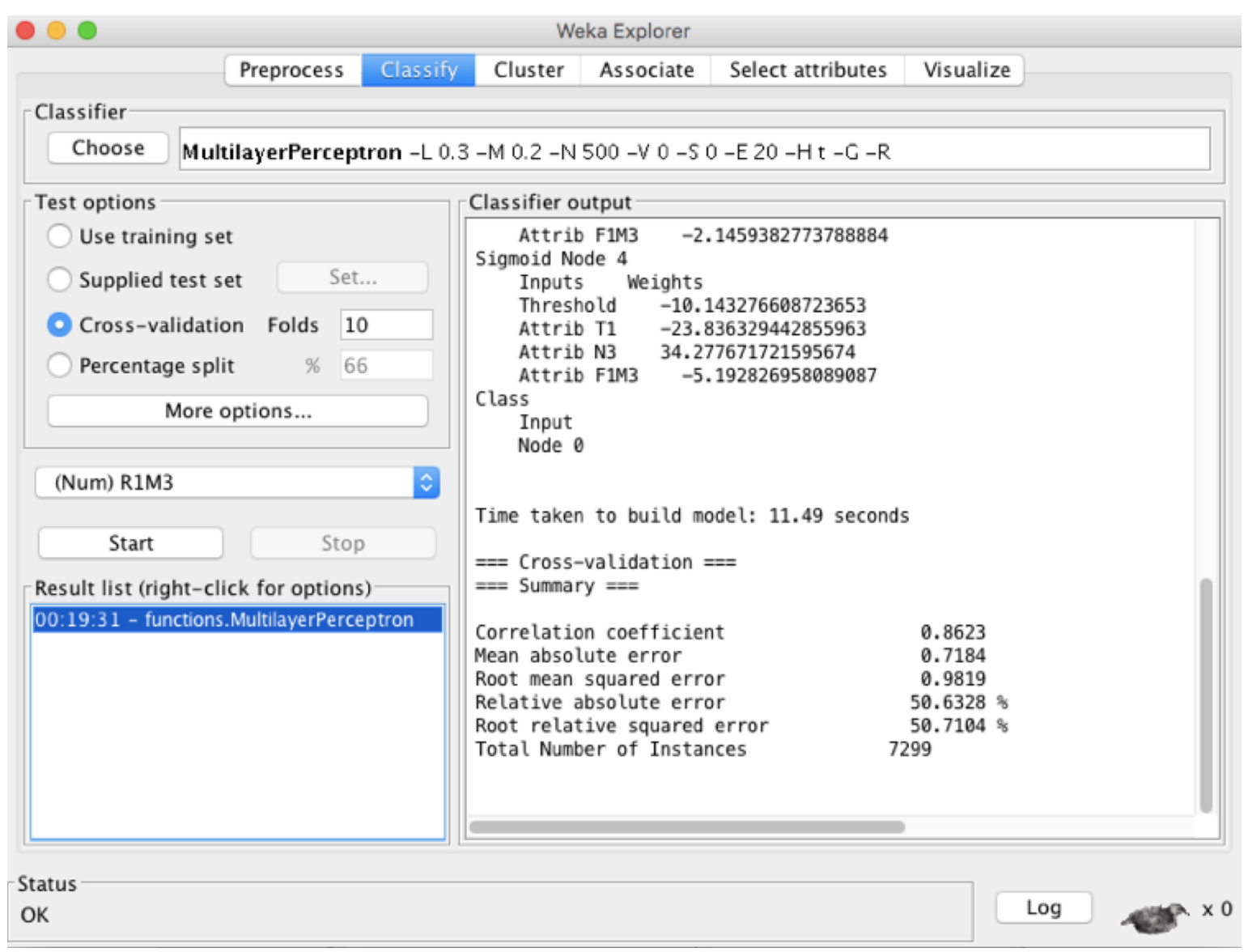

Figura 8 - Tela de classificação do Weka

\subsection{ALGORITMO OCFRN}

Muitas redes neurais são construídas usando-se uma camada de entrada, pelo menos uma cada escondida e uma camada de saída. Usando essa metodologia, cada camada tem uma total conectividade com a camada subsequente. Este trabalho usa um algoritmo de colônia de formigas para fazer buscas no grafo construído com os neurônios de uma rede de três camadas. $\mathrm{O}$ algoritmo de busca sugere as melhores conexões entre os neurônios, incluindo conexões diretas da camada de entrada para a camada de saída. Isso leva à 
criação de uma rede cuja topologia possui conexões arbitrárias. Como o algoritmo proposto utiliza a OCF para otimizar RNA, ele foi nomeado OCFRN.

O primeiro passo no algoritmo OCF proposto é construir o grafo que contém os componentes da solução. Em seguida, cada formiga da colônia constrói uma solução candidata após explorar o espaço de busca e sugere uma topologia de rede com sugestões de conexões entre neurônios. Quatro tipos de conexões são permitidas: conexões entre neurônios da camada de entrada e da camada escondida; conexões entre os neurônios de entrada e os neurônios de saída; conexões entre neurônios da camada escondida e a camada de saída; conexões entre neurônios da camada escondida. Cada conexão potencial $c=i \rightarrow$ $j$, conectando os neurônios $i$ e $j$, é associada com duas componentes de solução: $D_{c}^{\text {true }}$, e $D_{c}^{\text {false }}$. Essas duas componentes representam, respectivamente, a decisão de incluir ou não incluir a conexão na topologia candidata atual.

O número de neurônios de entrada $\left(N_{i}\right)$ e neurônios de saída $\left(N_{o}\right)$ foram determinados baseados nas características do conjunto de dados utilizado. Foi decidido que as topologias criadas seriam de três camadas pois esta é a forma mais comum de construir redes neurais artificiais. O número de neurônios na camada escondida $\left(N_{h}\right)$ foi configurado para ser escolhido arbitrariamente através de parâmetros de configuração.

Uma visão geral do algoritmo OCFRN está mostrado no Algoritmo 1. Inicialmente, a quantidade de feromônio em cada aresta do grafo é definida como 0,5 (linha 3). Isso significa que, para cada conexão, a probabilidade de incluí-la na topologia é igual à probabilidade de não incluí-la. Dentro do loop interno (linhas 6-12), cada formiga cria uma solução candidata $N N_{i}$ (linha 7). Então, na linha 8, a qualidade da solução é calculada. Na linha 13, a trilha de feromônio é atualizada com base na qualidade de $N N_{\text {thebest }}$ (a melhor topologia sugerida durante a iteração atual). Em seguida, a melhor solução encontrada na iteração atual é comparada com a melhor solução encontrada no geral (linhas 14-16), mantendo-se assim uma referência para a melhor solução encontrada durante a execução do algoritmo. 


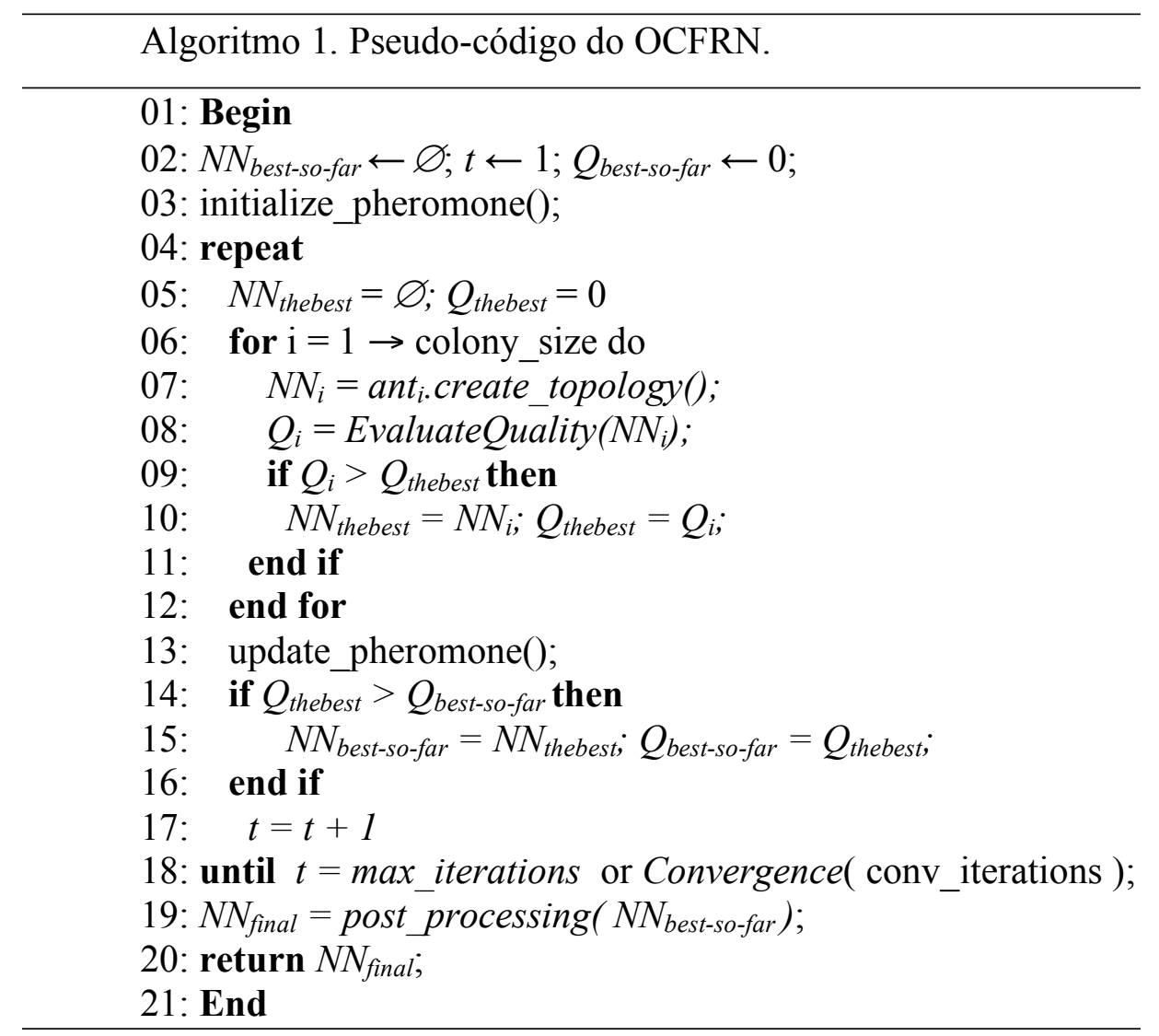

Esses passos são repetidos até que a mesma solução seja gerada por um número consecutivo de iterações, definido no parâmetro conv_iterations ou até que um número máximo de iterações seja alcançado (linha 18). Os experimentos realizados neste projeto, com diferentes configurações, levando-se em conta o resultado obtido e o tempo de execução levaram às seguintes escolhas: max_iterations foi configurado como 200; colony_size, que representa o número de formigas (linha 6), foi definido como 20. A Figura 9 apresenta um diagrama de blocos que sintetiza o funcionamento do algoritmo OCFRN. 


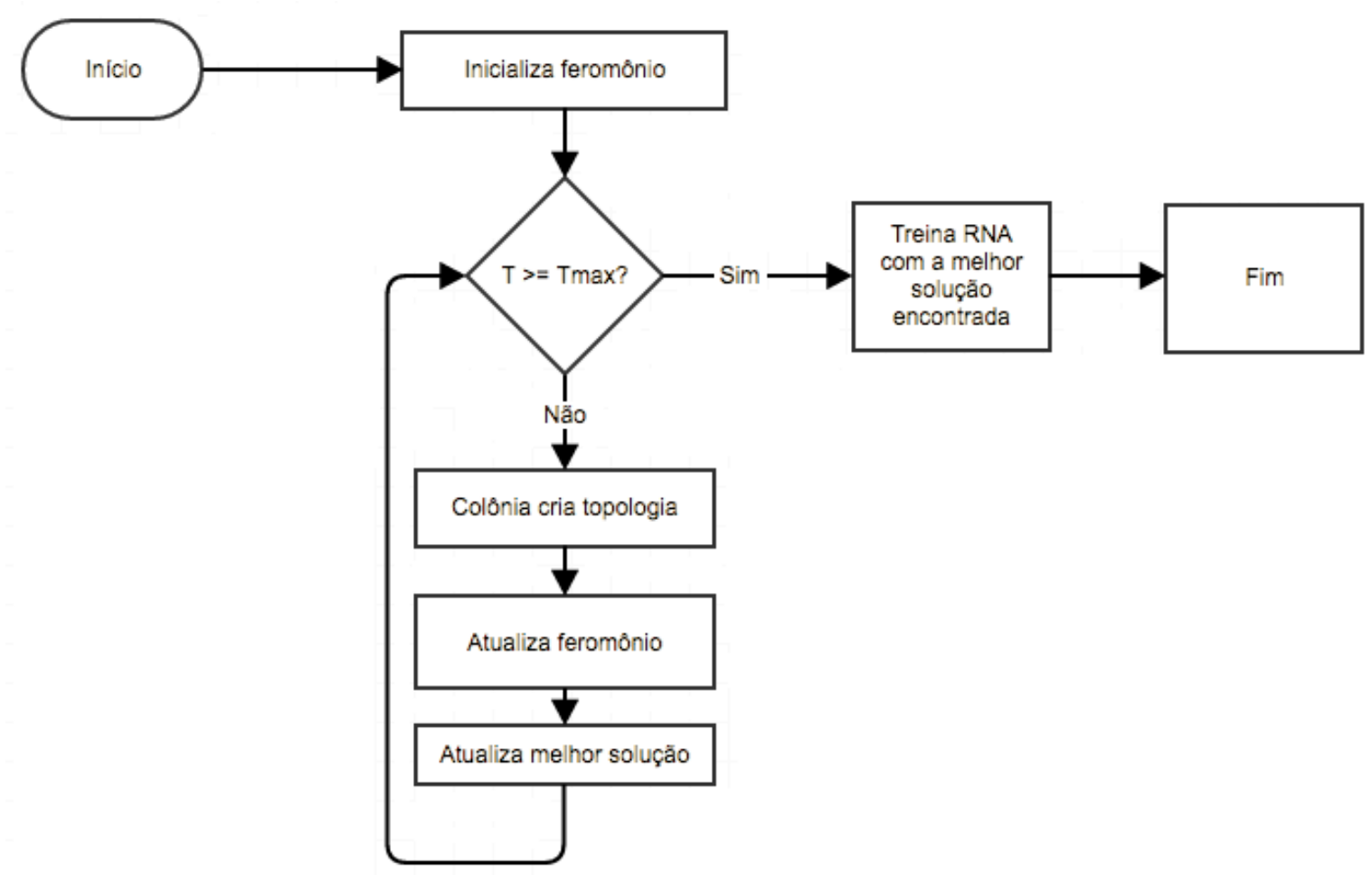

Figura 9 - Diagrama de blocos do algoritmo OCFRN

Na linha 19, a melhor topologia encontrada até o momento é usada para treinar (usando o algoritmo de retropropagação de erro) uma rede neural final que será retornada como resultado. Neste passo, usando as conexões sugeridas pelas formigas, os pesos e bias da rede neural são aprendidos. A comparação de resultados e de tempo de execução com diferentes configurações levou à escolha da taxa de aprendizado como 0,3, do momentum como 0,2 e do número de iterações como 500.

O processo de criar uma solução candidata (linha 7) inicia com um grafo sem arestas cujas conexões serão escolhidas durante o procedimento. Para cada conexão no conjunto de conexões disponíveis, a formiga decide se vai incluí-la ou não na topologia candidata. Isso é feito ao se escolher $D_{c}^{\text {true }}$ ou $D_{c}^{\text {false }}$, baseado na equação probabilística de transição de estado a seguir [22]:

$$
p\left(D_{c}^{a}\right)=\frac{\tau\left(D_{c}^{a}\right)}{\tau\left(D_{c}^{\text {true }}\right)+\tau\left(D_{c}^{\text {false }}\right)}
$$

onde $p\left(D_{c}^{a}\right)$ é a probabilidade de se selecionar a decisão $D^{a}$ para uma conexão $c$ e $\tau\left(D_{c}^{a}\right)$ é a quantidade de feromônio atual associada com a componente $D_{c}^{a}$ (onde $a=$ true ou $a=$ false). 
Depois que uma formiga encontra uma solução, ela calcula sua qualidade treinando uma rede neural usando retropropagação de erro (linha 8 do Algoritmo 1) com valores otimizados de parâmetros (por exemplo, neste trabalho a quantidade de iterações foi limitada para apenas 10). Para se minimizar problemas de sobreajustamento, o conjunto de dados foi dividido e o treinamento aconteceu usando-se a técnica de validação cruzada em partes. Para se calcular a qualidade das soluções candidatas foi utilizado o coeficiente de correlação, um método estatístico para se avaliar predições numéricas. Esse coeficiente mede a correlação entre os valores preditos nas instâncias e seus valores verdadeiros. Ele varia de 1 para resultados perfeitamente correlacionados, passando por 0 quando não há correlação, até -1 quando os resultados são perfeitamente relacionados negativamente [45].

Embora o algoritmo OCFRN produza topologias onde há conexões entre neurônios da camada escondida, uma restrição foi feita para garantir que as redes resultantes não sejam do tipo recorrente. Na camada escondida, os neurônios $i$ e $j$ só podem ser conectados se $j>i$. Na Figura 10, numerando os neurônios da camada escondida de cima para baixo, os neurônios conectam-se de forma a permitir que o sinal se propague verticalmente para baixo, sem que haja retroalimentação. Assim, a rede pode ser classificada como de propagação para frente (com fluxo da esquerda para a direita, e, na camada escondida, de cima para baixo). Quando aplicado o algoritmo de retropropagação, o sinal se propaga da direita para a esquerda e, na camada escondida, de baixo para cima.

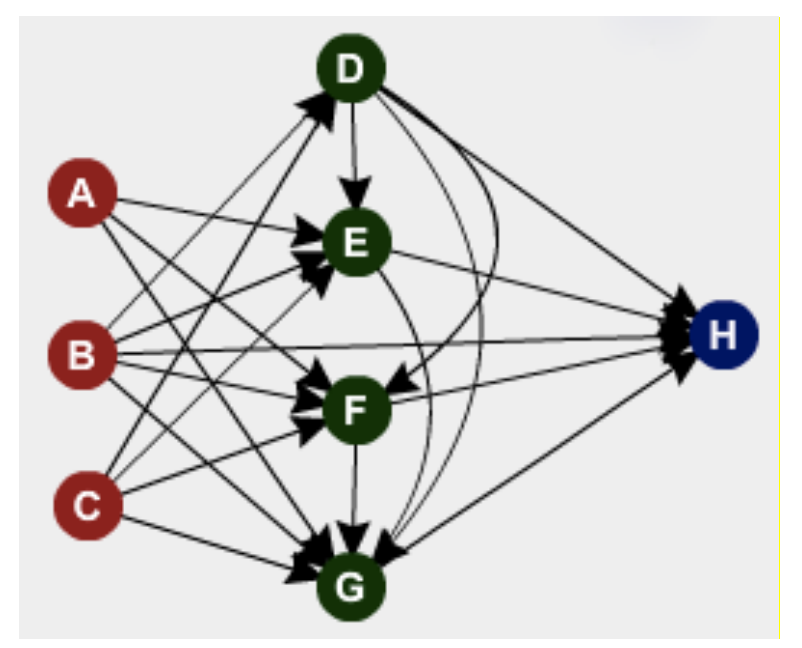

Figura 10 - Conexões entre neurônios da camada escondida no algoritmo OCFRN 
Apesar da restrição no algoritmo OCFRN que garante que não haja retroalimentação, as formigas artificiais podem sugerir topologias que não convergem. Por exemplo, o neurônio da camada de saída pode ficar isolado caso nenhuma conexão da camada escondida até ele seja escolhida, como mostrado na Figura 11. No algoritmo OCFRN, topologias como esta seriam prontamente descartadas, pois seu coeficiente de correlação seria ruim (o erro da rede ficaria inalterado durante as iterações, sem que houvesse convergência) em relação ao das redes com topologia válida. Outra forma de garantir que topologias inválidas sejam descartadas é fazer com que toda topologia sugerida pela colônia que cause erro na execução do Weka receba um coeficiente de correlação como zero (o pior possível).

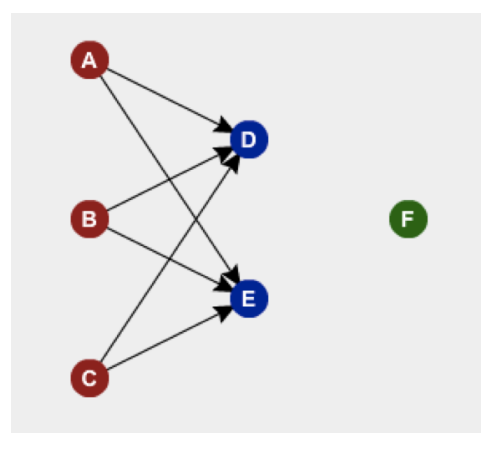

Figura 11 - Topologia inválida criada pelo algoritmo OCFRN

\subsubsection{Procedimento para criação de topologia}

O Algoritmo 2 descreve o processo de criar uma solução candidata (topologia para uma RNA). O procedimento inicia com um grafo sem arestas e cujos nós são os neurônios de uma RNA (linha 2). As arestas são selecionadas durante o procedimento. Na linha 2 também é criado um grafo que representa as trilhas que podem ser utilizadas pelas formigas. Na linha 3, $|\mathrm{C}|$ representa todas as arestas possíveis do grafo, ou seja, cada uma das ligações possíveis entre neurônios. 
A Figura 12 apresenta um exemplo de grafo de trilhas para uma rede neural com uma entrada, uma saída e três neurônios na camada escondida. Entre todos os nós que podem ser conectados, há duas arestas, uma chamada true e outra chamada false. Uma formiga $a$, posicionada no nó $i$, deve decidir se segue a aresta true ou a aresta false até o nó $j$ (linha 4). Caso a aresta escolhida seja a true, haverá, na topologia sugerida pela formiga, uma conexão entre os nós $i$ e $j$ (linhas 6 e 7).

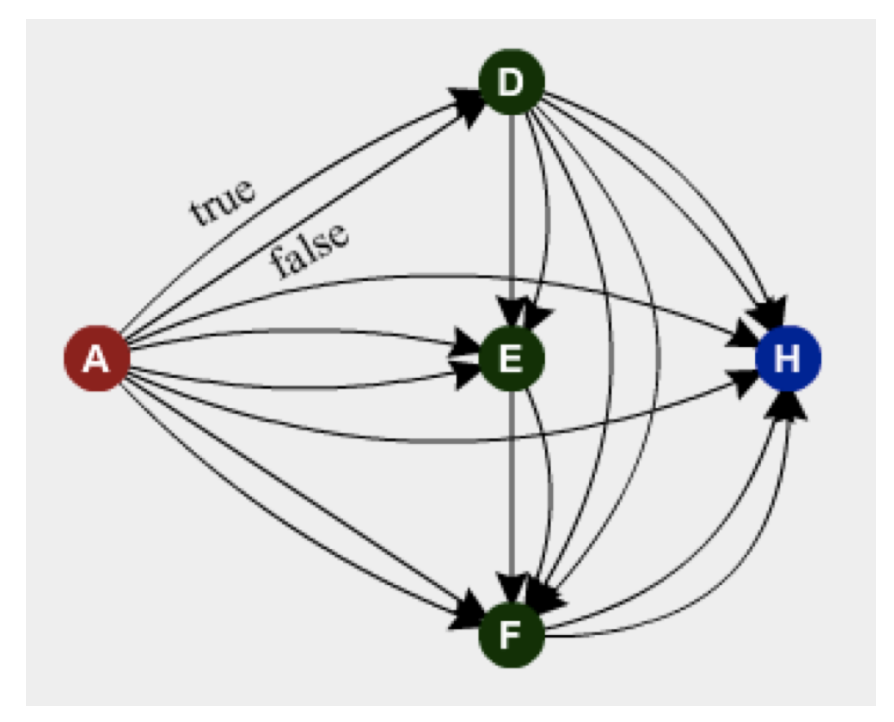

Figura 12 - Exemplo de um grafo de trilhas que podem ser seguidas

Na linha 10 do Algoritmo 2 a topologia escolhida pela formiga é utilizada para treinar uma RNA. Nessa etapa, o treinamento da RNA é feito de forma rápida, utilizando parâmetros otimizados. Como exemplos de simplificações podem ser citados:

- Número de iterações;

- Número de partições para dividir o conjunto de dados (utilizando a validação cruzada); 
Algoritmo 2. Procedimento para criação de topologia

01: Begin create_topology()

02: NN $\varnothing ;$;railGraph $\leftarrow \varnothing$

03: for $c=1 \rightarrow|\mathrm{C}|$ do

04: $D_{c}{ }^{a}=$ select_decision_component();

05: TrailGraph $=$ TrailGraph $\cup D_{c}$;

06: if $D_{c}^{a}==D_{c}^{\text {true }}$ then

07: $\quad N N=N N \cup(i \rightarrow \mathrm{j})_{c}$;

08: end if

09: end for

10: train_neural_network $(N N)$

11: return $N N$;

12: End

\subsection{Programação do algoritmo OCFRN}

Inicialmente foi construído um programa na linguagem Python capaz de treinar e testar a qualidade de uma rede neural dada uma lista de conexões entre os neurônios. Como parâmetro de "qualidade" foi escolhido o coeficiente de correlação. O maior problema de se trabalhar com esse programa foi dificuldade de incluir nele um algoritmo para fazer validação cruzada com $n$ partições.

Para minimizar problemas de sobreajustamento, foi decidido que o treinamento seria feito utilizando validação cruzada. Devido a essa decisão e também ao fato do programa de aprendizado de máquina Weka já incluir esse método de teste como opção, escolheu-se trabalhar com o Weka na parte de treinamento da rede neural ao invés do programa escrito em Python. Porém, como o algoritmo do Weka não permite criar, de forma automática, redes neurais selecionando quais neurônios devem ser conectados, decidiu-se que o seu código fonte (que é software livre) seria alterado para atender às necessidades. Assim, o código Java foi modificado para permitir conexões arbitrárias entre neurônios e para permitir conexões entre neurônios da camada escondida. Embora o Weka original permita a conexão arbitrária de neurônios, isso só pode ser feito através de uma interface gráfica. Assim, foi necessária uma atualização no código fonte que permitisse passar como parâmetro um conjunto de arestas a serem ativadas na topologia de RNA. 
O algoritmo OCFRN foi programado na linguagem Python. Um programa foi escrito nessa linguagem e projetou uma colônia de formigas capaz de testar redes neurais com diferentes topologias. Ao executar o código, é possível alterar os seguintes parâmetros:

- Número de formigas;

- Número de iterações - o número de vezes que cada formiga percorre o grafo;

- Arquivo de entrada - arquivo com os dados de treinamento;

- Número de iterações para treinar a rede neural escolhida como melhor;

- Número de iterações para estimar a qualidade de uma topologia;

- Número de neurônios na camada escondida;

- Taxa de aprendizado da rede neural;

- Momentum da rede neural;

- Convergência - número de saídas repetidas a partir do qual o OCFRN para de executar novas iterações;

Inicialmente o algoritmo OCFRN cria uma lista de todas as arestas possíveis no grafo que tem $i$ entradas, $h$ neurônios na camada escondida e $o$ saídas. Inicialmente, cada aresta tem $50 \%$ de chance de ser selecionada para fazer parte do grafo. As formigas criam topologias incluindo ou excluindo do grafo cada aresta possível. A cada iteração, a melhor solução encontrada pela colônia é utilizada para atualizar a quantidade de feromônio nas arestas selecionadas.

Cada uma das formigas testa a qualidade da topologia que constrói durante as iterações. Para isso, faz uma requisição à versão modificada do Weka, que retorna como resultado o coeficiente de correlação. O algoritmo repete a construção de topologias pela colônia de formigas até que um número máximo de iterações aconteça ou até que a colônia retorne como solução uma mesma topologia por um número $n$ repetido de vezes.

\subsection{Conjuntos de dados}

Neste trabalho foram utilizadas dois conjuntos de dados contendo informações das variáveis monitoradas pelo SAD. Os dados são referentes a uma semana típica de operação do reator IEA-R1. Cada conjunto possui aproximadamente 7000 instâncias e quatro atributos. Para este trabalho, foram escolhidas duas importantes variáveis para serem monitoradas utilizando-se o algoritmo OCFRN: taxa de dose no saguão da piscina e temperatura da piscina acima do núcleo do reator. 
O primeiro conjunto de dados contém informações das variáveis T1, N3, F1M3 e R1M3. As três primeiras variáveis foram utilizadas como entradas nas redes neurais enquanto a última foi utilizada como saída. A variável R1M3 é de extrema importância na monitoração do reator IEA-R1 porque ela representa o valor da taxa de dose na ponte de sustentação do núcleo, lado esquerdo.

O segundo conjunto de dados contém informações das variáveis N2, N3, N4 e T1. A variável T1, que mede a temperatura na superfície da piscina, foi utilizada como saída no treinamento das redes neurais enquanto as demais variáveis foram utilizadas como entrada.

\subsubsection{Formato dos conjuntos de dados}

Para trabalhar com um conjunto de dados no Weka é necessário que ele esteja num formato específico, com extensão $A R F F$. A Figura 13 apresenta uma parte do conjunto de dados que foi construído com as variáveis T1, N3, F1M3 e R1M3. As linhas começando com o símbolo “\%” são comentários. A palavra-chave @relation define um nome para a relação. As linhas iniciadas com@attribute contêm os atributos do conjunto de dados e seus respectivos formatos (na figura, todos os atributos estão em formato numérico). A palavra-chave@data marca o início dos dados propriamente ditos. Estes ficam organizados de forma que cada linha representa uma instância e os atributos ficam separados por vírgula. 


\% Base de dados 1
@relation T1_N3_F1M3_R1M3
@attribute T1 numeric
@attribute N3 numeric
@attribute F1M3 numeric
@attribute R1M3 numeric
@)data
$21.2,0.00,207.29,0.4$
$21.3,0.00,153.09,0.4$
$21.2,0.00,229.64,0.4$
$21.1,0.00,207.29,0.4$

Figura 13 - Conjunto de dados em formato ARFF

\subsubsection{Criação de Modelos}

Como mostra a Figura 14, após treinar uma Rede Neural Artificial no Weka é possível guardar o modelo matemático criado para posterior utilização. Isso permite aplicar modelos salvos em conjuntos de dados novos. Para aplicar os modelos criados neste projeto aos conjuntos de dados e finalmente os resultados no formato CSV (valores separados por vírgulas) foram utilizados comandos na linguagem Java como:

java -cp weka.jar

weka.classifiers.functions.MultilayerPerceptron -T dados.arff -1 modelo.model -p 0 -classifications

weka.classifiers.evaluation.output.prediction.CSV 


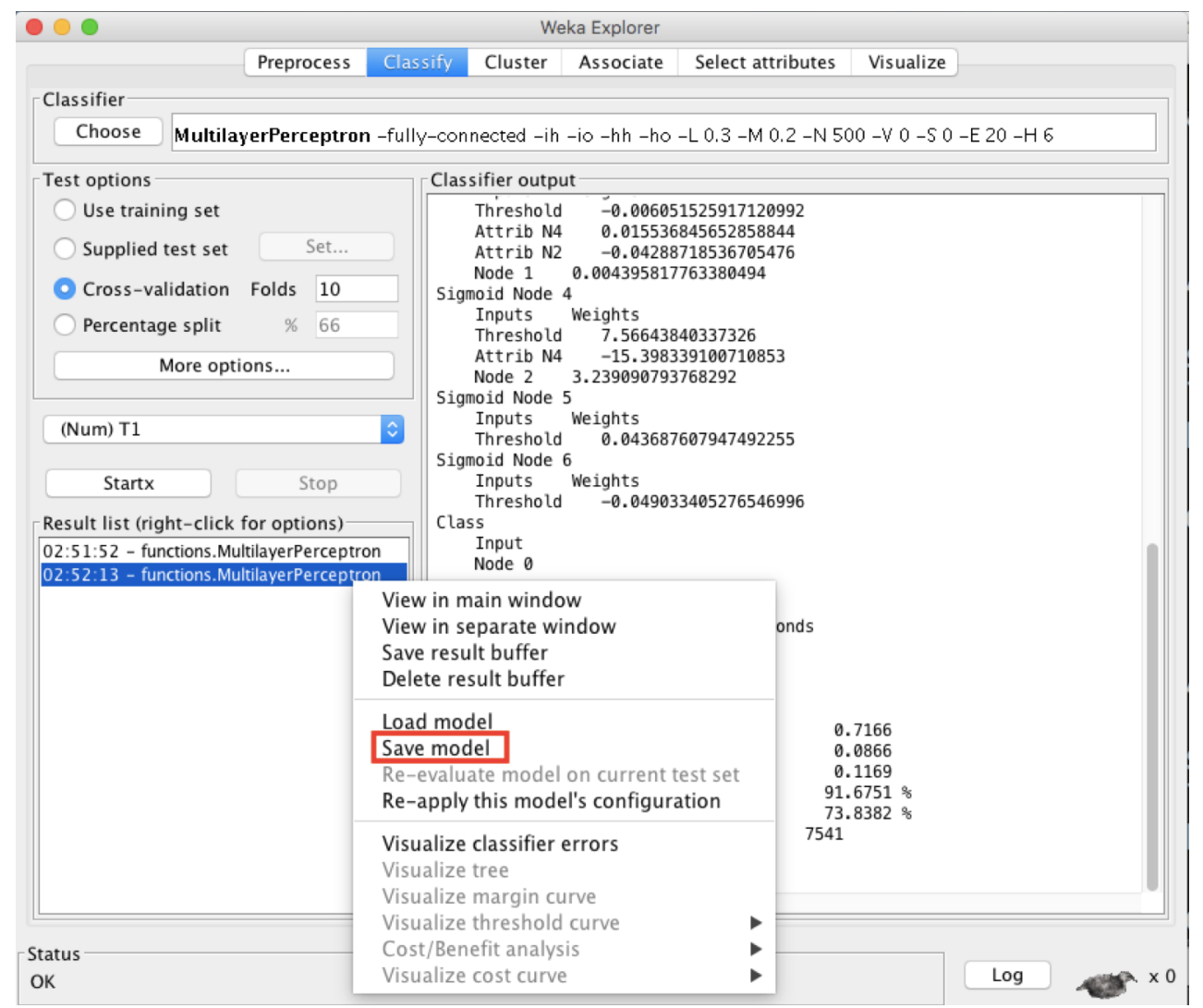

Figura 14 - Criação de modelo usando RNA no Weka

\subsubsection{Treinamento das Redes Neurais Artificiais}

Devido ao número de atributos nas instâncias das bases de dados, as redes neurais treinadas foram configuradas para ter três neurônios na camada de entrada e um neurônio na camada de saída. O número de neurônios na camada escondida foi planejado para ser arbitrário e definido através de um parâmetro de configuração, ou seja, antes de executar o algoritmo OCFRN é necessário escolher quantos neurônios estarão disponíveis na camada escondida da RNA.

Usando redes neurais com 3 entradas e 1 saída, as duas bases de dados escolhidas para este projeto foram utilizadas para treinar redes neurais totalmente conectadas. As figuras 11, 12 e 13 apresentam a topologia dessas redes para uma configuração com 4, 5 e 6 neurônios na camada escondida, respectivamente. 


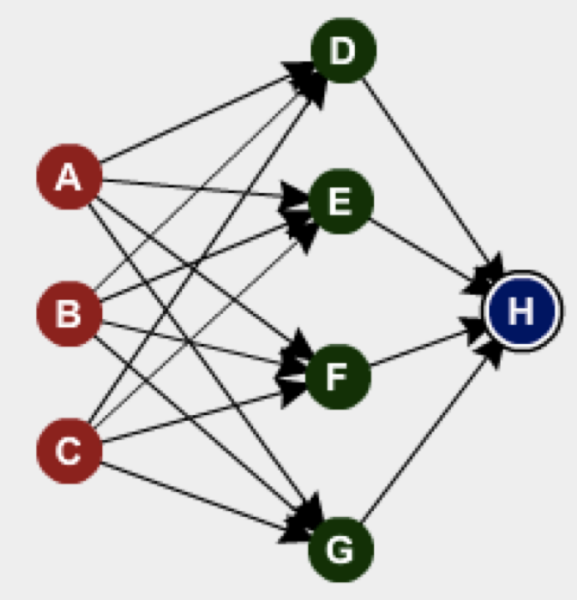

Figura 15 - Rede neural totalmente conectada com 4 neurônios na camada escondida

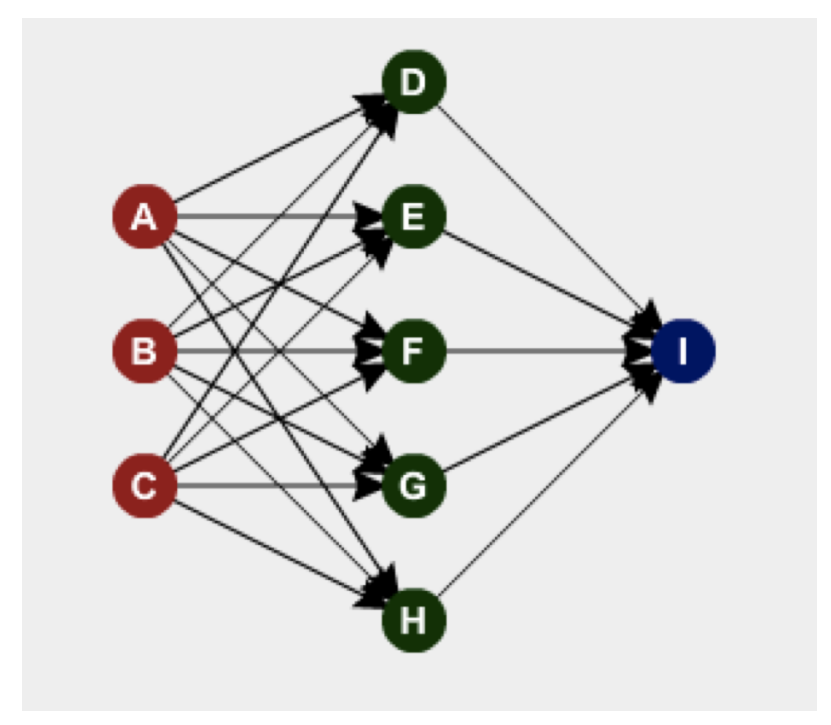

Figura 16 - Rede neural totalmente conectada com 5 neurônios na camada escondida 


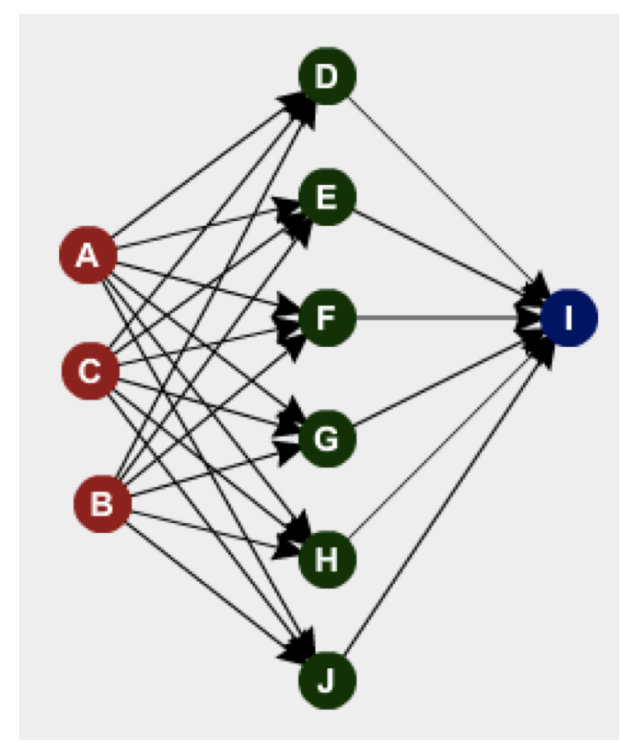

Figura 17 - Rede neural totalmente conectada com 6 neurônios na camada escondida

O algoritmo OCFRN foi usado para criar redes neurais com topologias otimizadas e seu desempenho foi comparado com o das redes totalmente conectadas equivalentes. Os testes foram executados com os seguintes parâmetros:

- Número de iterações para treinar as redes neurais: 500. Testes com um número maior de iterações aumentava o tempo de processamento sem que houvesse melhoria significativa do resultado.

- Número de formigas: 20 - Os testes mostraram que para os conjuntos de dados utilizados neste trabalho, um número de formigas maior que 20 aumentava muito o tempo de execução sem, no entanto, melhorar os resultados.

- Taxa de aprendizado das redes neurais: 0,3. Como o objetivo era comparar o desempenho das RNA totalmente conectadas com o das RNA otimizadas, diferenciando-as apenas pela topologia, a taxa de aprendizado foi configurada com o valor padrão do Weka.

- Número de iterações para estimar a qualidade de uma rede neural: 20 (com validação cruzada de 3 partições).

- Número de repetições: 30 - a busca foi repetida 30 vezes, reiniciando, a cada uma delas, o feromônio das arestas do grafo para as condições iniciais.

- Método de teste do modelo para cada topologia sugerida pela colônia de formigas: validação cruzada com 3 partições. 
- Método de teste do modelo final: validação cruzada com 10 partições.

Com essas configurações, em cada um dos conjuntos de dados utilizados neste projeto, o algoritmo OCFRN demorou aproximadamente 60 minutos para escolher a melhor topologia e criar o modelo. 


\section{RESULTADOS}

Neste trabalho foram escolhidas duas importantes variáveis do reator de pesquisas IEA-R1: a taxa de dose no saguão da piscina (R1M3) e a temperatura da água da piscina acima do núcleo do reator (T1). Nos dois casos, foram escolhidas três variáveis de entrada para a criação dos modelos. Para estimar R1M3, foram utilizadas T1 (temperatura na superfície da piscina), N3 (percentual de potência no canal de segurança 2) e F1M3 (vazão do primário). As estimativas de T1 foram feitas utilizando como entradas as variáveis N2 (percentual de potência no canal de segurança 1), N3 (percentual de potência no canal de segurança 2) e N4 (percentual de potência no canal de segurança 3).

Foram feitos experimentos para estimar R1M3 e T1 com redes neurais totalmente conectadas e com redes otimizadas. A versão padrão do Weka foi utilizada nos cálculos envolvendo as redes totalmente conectadas, enquanto que o algoritmo OCFRN e a versão personalizada do Weka foram utilizados nos cálculos das redes otimizadas. Os experimentos foram repetidos com 4, 5 e 6 neurônios na camada escondida. A seguir são apresentados os resultados obtidos em cada caso. Nas comparações de resultados foram incluídas, além do coeficiente de correlação, duas outras medidas de desempenho: o erro absoluto médio e o erro quadrático médio. Essas duas medidas foram acrescentadas para que se possa verificar de forma mais ampla a diferença de desempenho entre os modelos.

\subsection{Estimando R1M3 a partir de T1, N3 e F1M3}

\subsubsection{Testes com quatro neurônios na camada escondida}

A Figura 18 apresenta a rede neural sugerida pelo algoritmo OCFRN para estimar o valor da variável R1M3 a partir das variáveis T1, N3 e F1M3 - configuração com 4 neurônios na camada escondida. Dentre outras, algumas diferenças em relação à rede totalmente conectada podem ser destacadas nessa figura: na topologia sugerida não há conexão entre a entrada A e o neurônio D, da camada escondida; há conexões entre neurônios da camada escondida; há uma conexão direta entre a entrada $\mathrm{B}$ e o neurônio da camada de saída. A Tabela 2 compara o desempenho da topologia otimizada com o da topologia totalmente conectada. 


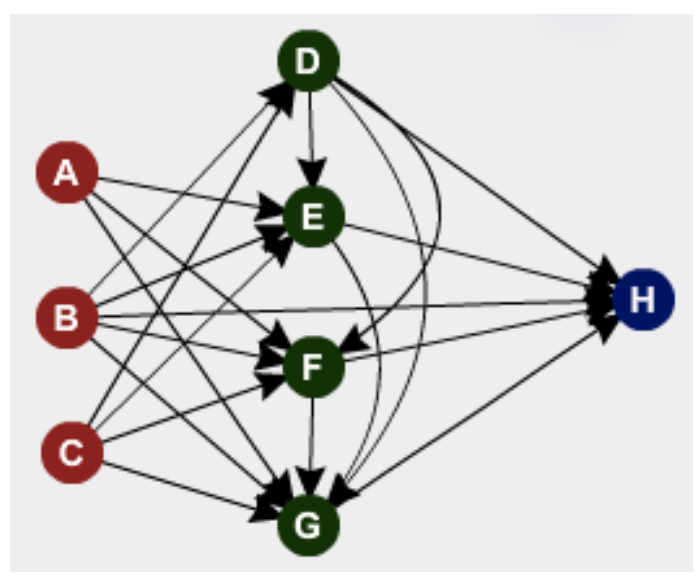

Figura 18 - Rede neural otimizada com as variáveis T1, N3, F1M3 e R1M3 (configuração com 4 neurônios na camada escondida)

Tabela 2 - Desempenho das RNA que estimam R1M3 com 4 neurônios na camada escondida

\begin{tabular}{|l|c|l|}
\hline & Totalmente conectada & Otimizada \\
\hline Coeficiente de correlação & 0,86 & 0,87 \\
\hline Erro absoluto médio & 0,72 & 0,72 \\
\hline Erro quadrático médio & 0,98 & 0,94 \\
\hline
\end{tabular}

A Figura 19 apresenta um gráfico que compara os valores estimados e reais para a variável R1M3, calculados pela RNA totalmente conectada com 4 neurônios na camada escondida. No gráfico da Figura 20 a mesma comparação é feita, mas para uma RNA otimizada, também com 4 neurônios na camada escondida. Nos dois gráficos, a curva azul é composta pelos valores reais enquanto a curva vermelha foi criada com os valores estimados pela RNA. 


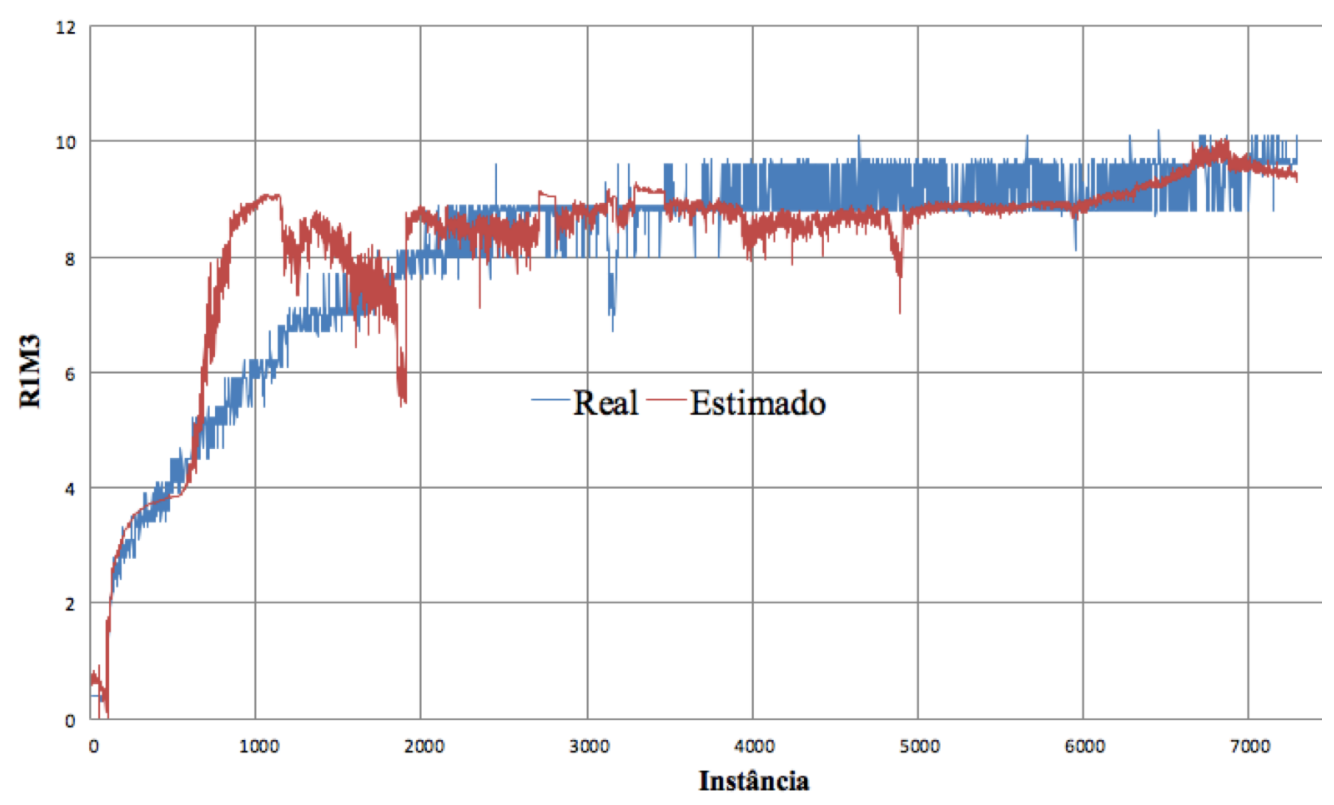

Figura 19 - Variável R1M3: saída desejada comparada com a saída obtida pela RNA totalmente conectada com 4 neurônios na camada escondida

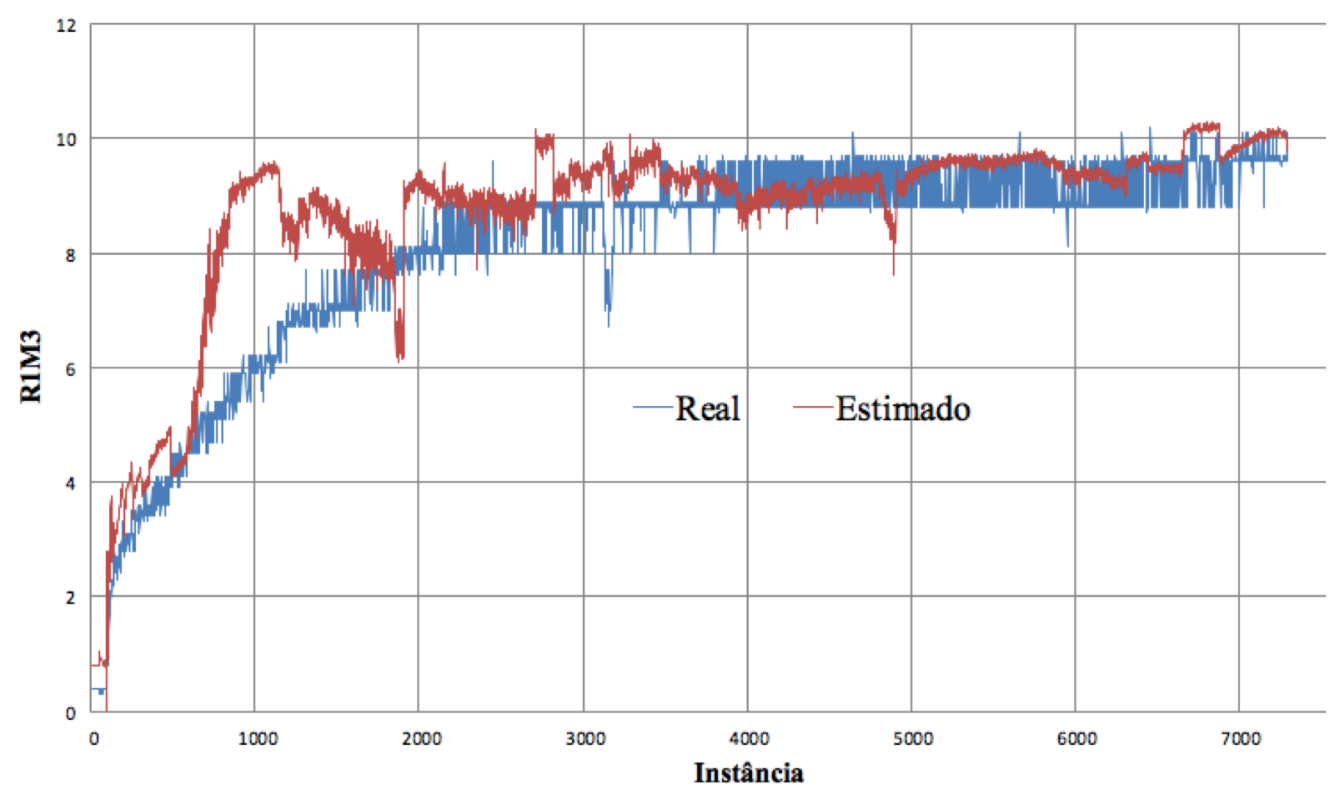

Figura 20 - Variável R1M3: saída desejada comparada com a saída obtida pela RNA otimizada com 4 neurônios na camada escondida 


\subsubsection{Testes com cinco neurônios na camada escondida}

A Figura 22 apresenta a rede neural sugerida pelo algoritmo OCFRN para estimar o valor da variável R1M3 a partir das variáveis T1, N3 e F1M3 - configuração com 5 neurônios na camada escondida. Dentre outras, algumas diferenças em relação à rede totalmente conectada podem ser destacadas nessa figura: na topologia sugerida, as entradas $A$ e $C$ estão ligadas a um único neurônio da camada escondida; há conexões entre neurônios da camada escondida; um dos neurônios da camada escondida está isolado (não foi utilizado). A Tabela 3 compara o desempenho da topologia otimizada com o da topologia totalmente conectada.

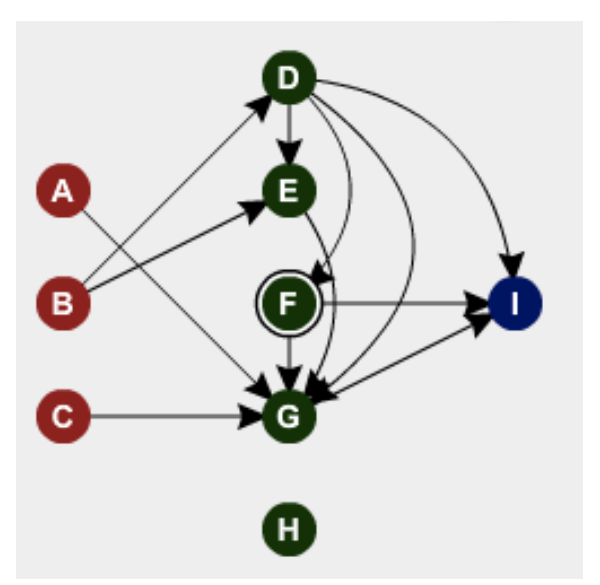

Figura 21 - Rede neural otimizada com as variáveis T1, N3, F1M3 e R1M3 (configuração com 5 neurônios na camada escondida)

A Figura 22 apresenta um gráfico que compara os valores estimados e reais para a variável R1M3, calculados pela RNA totalmente conectada com 5 neurônios na camada escondida. No gráfico da Figura 25 a mesma comparação é feita, mas para uma RNA otimizada, também com 5 neurônios na camada escondida. Nos dois gráficos, a curva azul é composta pelos valores reais enquanto a curva vermelha foi criada com os valores estimados pela RNA. 
Tabela 3 - Desempenho das RNA que estimam R1M3

com 5 neurônios na camada escondida

\begin{tabular}{|l|c|l|}
\hline & Totalmente conectada & Otimizada \\
\hline Coeficiente de correlação & 0,86 & 0,87 \\
\hline Erro absoluto médio & 0,71 & 0,70 \\
\hline Erro quadrático médio & 0,97 & 0,94 \\
\hline
\end{tabular}

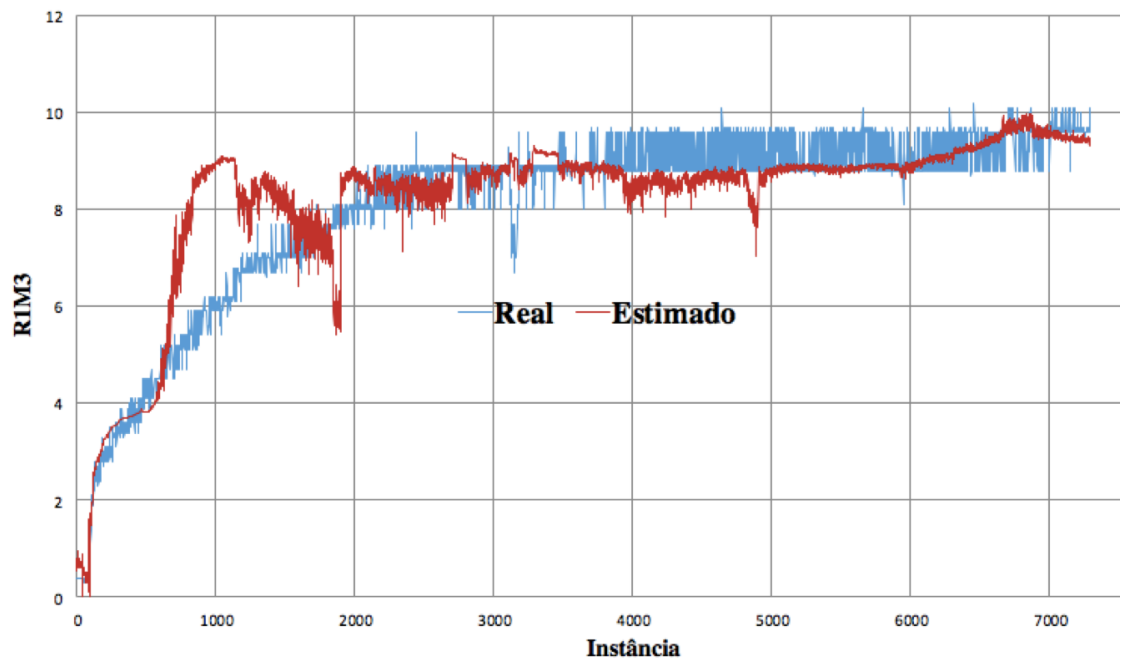

Figura 22 - Variável R1M3: saída desejada comparada com a saída obtida pela RNA totalmente conectada com 5 neurônios na camada escondida 


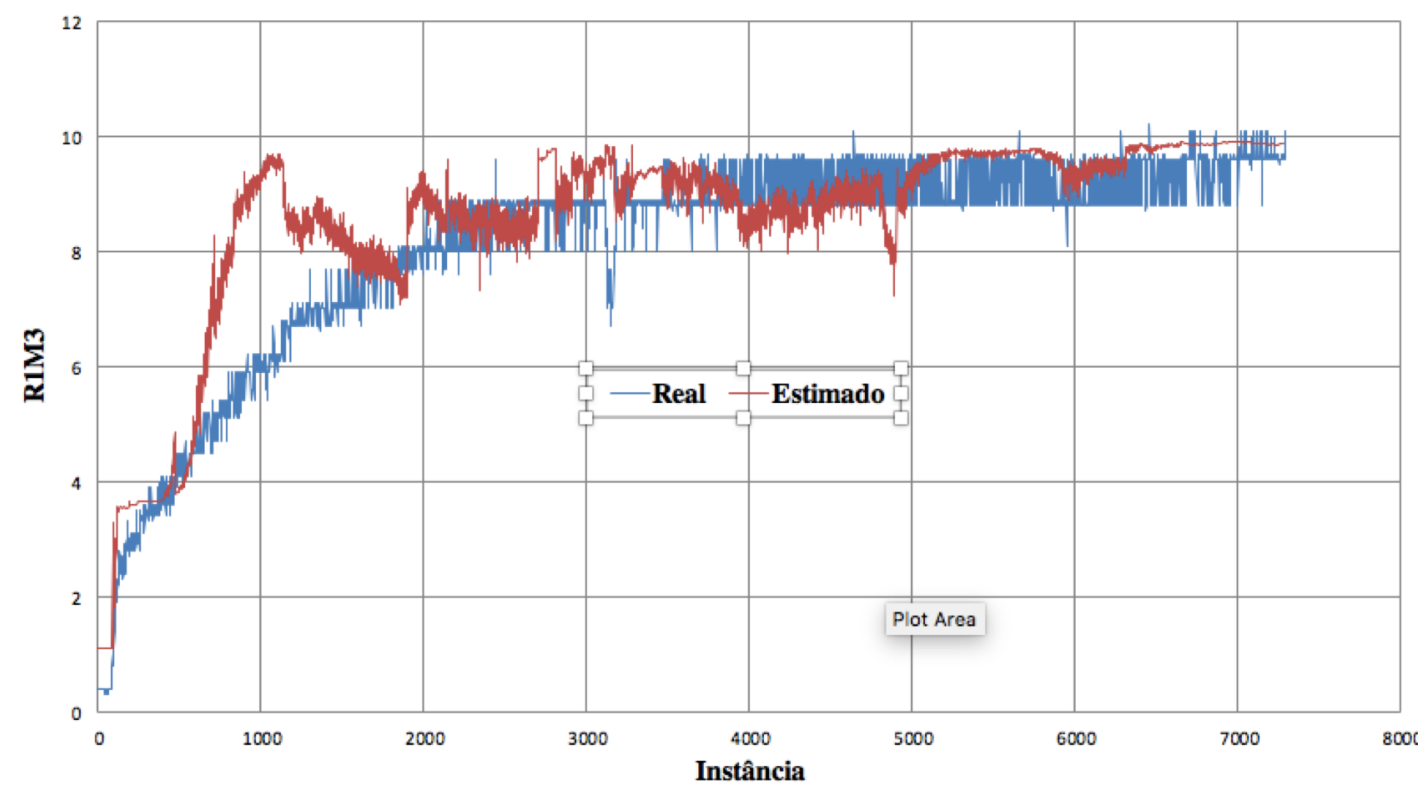

Figura 23 - Variável R1M3: saída desejada comparada com a saída obtida pela RNA otimizada com 5 neurônios na camada escondida

\subsubsection{Testes com seis neurônios na camada escondida}

A Figura 24 apresenta a rede neural sugerida pelo algoritmo OCFRN para estimar o valor da variável R1M3 a partir das variáveis T1, N3 e F1M3 - configuração com 6 neurônios na camada escondida. Dentre outras, algumas diferenças em relação à rede totalmente conectada podem ser destacadas nessa figura: na topologia sugerida, cada uma das entradas está ligada a apenas dois neurônios na camada escondida; há conexões entre neurônios da camada escondida; um dos neurônios da camada escondida está isolado (não foi utilizado). A Tabela 4 compara o desempenho da topologia otimizada com o da topologia totalmente conectada. 


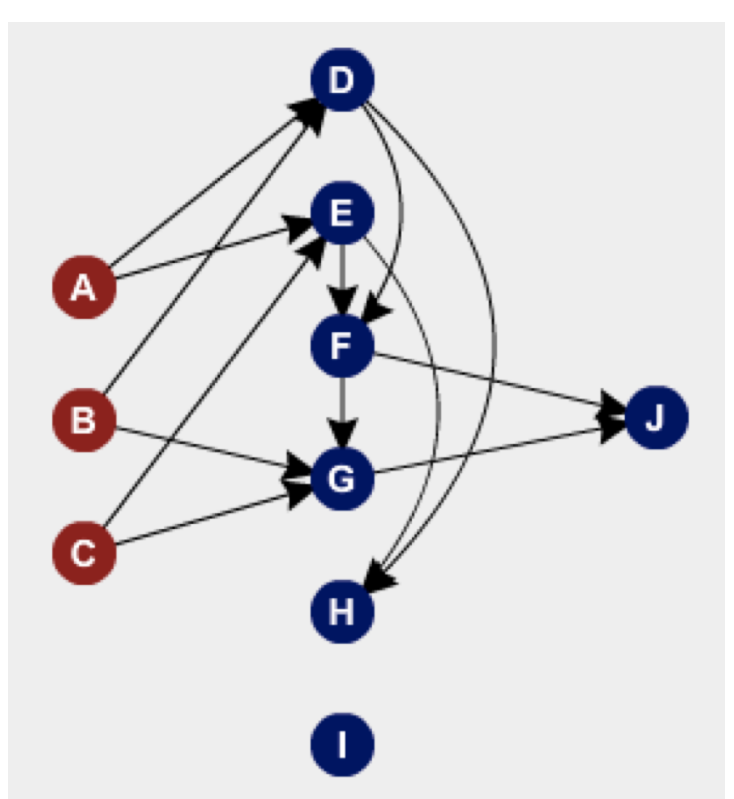

Figura 24 - Rede neural otimizada com as variáveis T1, N3, F1M3 e R1M3 (configuração com 6 neurônios na camada escondida)

A Figura 25 apresenta um gráfico que compara os valores estimados e reais para a variável R1M3, calculados pela RNA totalmente conectada com 6 neurônios na camada escondida. No gráfico da Figura 26 a mesma comparação é feita, mas para uma RNA otimizada, também com 6 neurônios na camada escondida. Nos dois gráficos, a curva azul é composta pelos valores reais enquanto a curva vermelha foi criada com os valores estimados pela RNA.

Tabela 4 - Desempenho das RNA que estimam R1M3 com 6 neurônios na camada escondida

\begin{tabular}{|l|c|l|}
\hline & Totalmente conectada & Otimizada \\
\hline Coeficiente de correlação & 0,86 & 0,88 \\
\hline Erro absoluto médio & 0,71 & 0,68 \\
\hline Erro quadrático médio & 0,98 & 0,91 \\
\hline
\end{tabular}




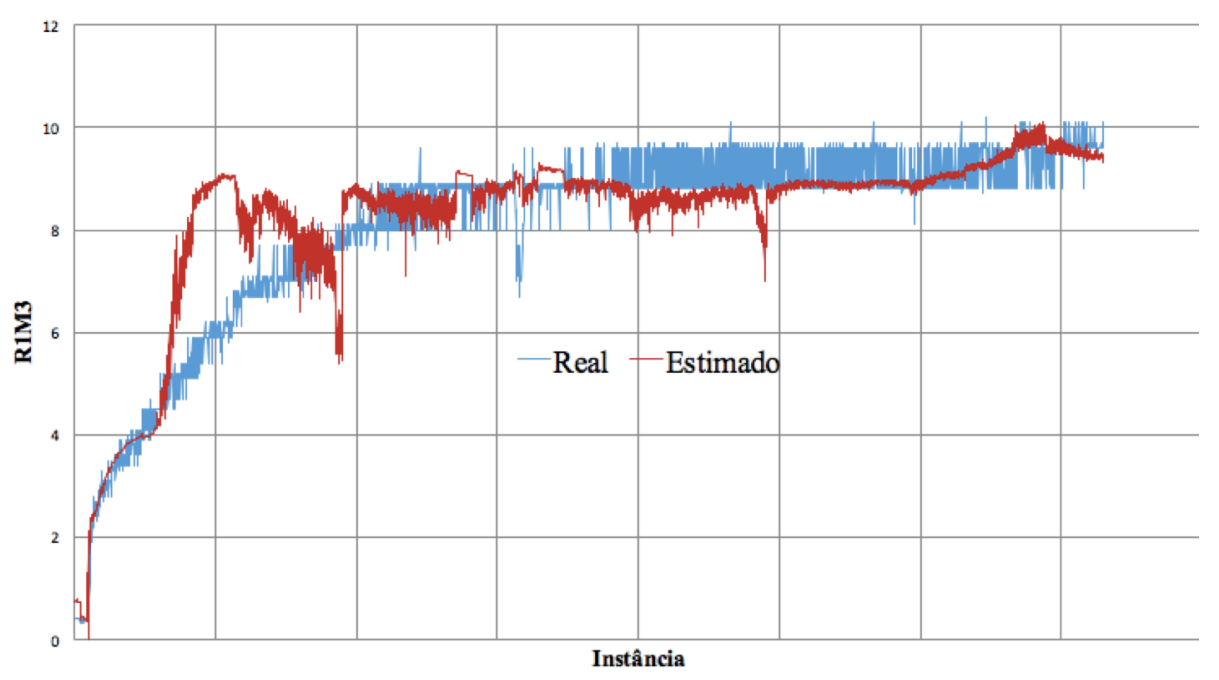

Figura 25 - Variável R1M3: saída desejada comparada com a saída obtida pela RNA totalmente conectada com 6 neurônios na camada escondida

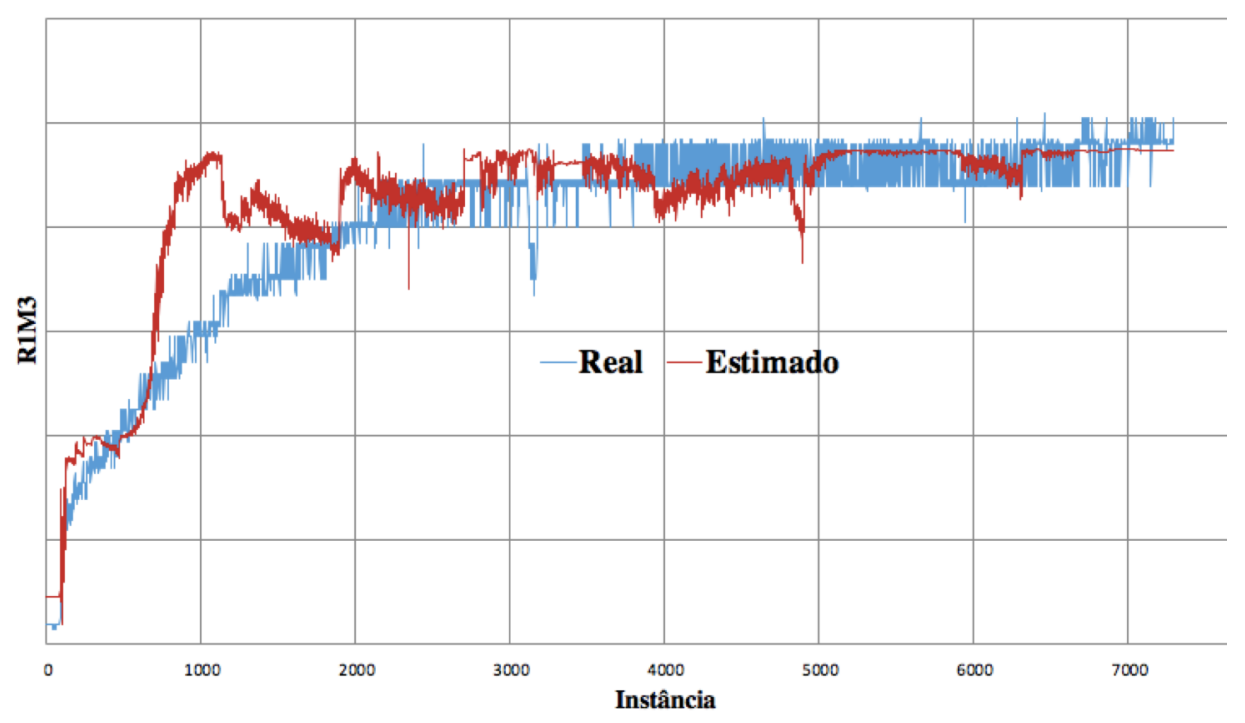

Figura 26 - Variável R1M3: saída desejada comparada com a saída obtida pela RNA otimizada com 6 neurônios na camada escondida 


\subsection{Estimando T1 a partir de N2, N3 e N4}

\subsubsection{Testes com quatro neurônios na camada escondida}

A Figura 27 apresenta a rede neural sugerida pelo algoritmo OCFRN para estimar o valor da variável T1 a partir das variáveis N2, N3 e N4 - configuração com 4 neurônios na camada escondida. Dentre outras, algumas diferenças em relação à rede totalmente conectada podem ser destacadas nessa figura: na topologia sugerida, a entrada $C$ está conectada a apenas um neurônio na camada escondida; há conexões entre neurônios da camada escondida; apenas dois neurônios da camada escondida estão conectados ao neurônio da camada de saída. A Tabela 5 compara o desempenho da topologia otimizada com o da topologia totalmente conectada.

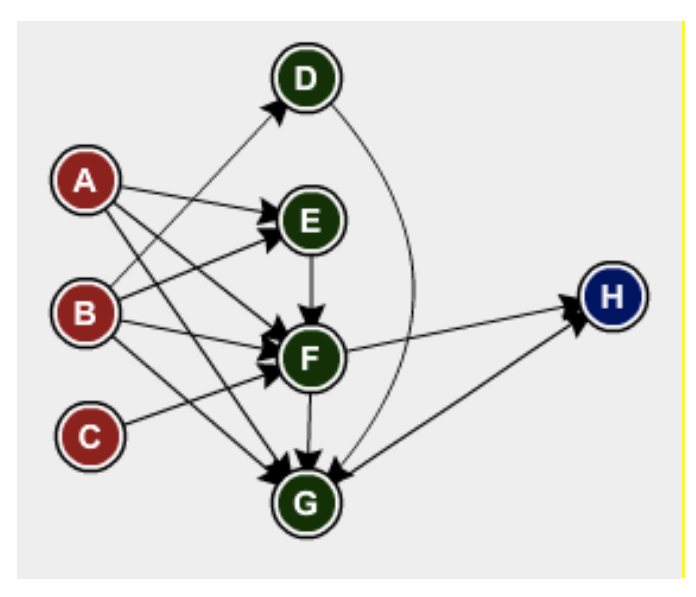

Figura 27 - Rede neural otimizada com as variáveis N2, N3, N4 e T1 (configuração com 4 neurônios na camada escondida)

Tabela 5 - Desempenho das RNA que estimam T1 com 4 neurônios na camada escondida

\begin{tabular}{|l|c|l|}
\hline & Totalmente conectada & Otimizada \\
\hline Coeficiente de correlação & 0,73 & 0,75 \\
\hline Erro absoluto médio & 0,08 & 0,08 \\
\hline Erro quadrático médio & 0,11 & 0,10 \\
\hline
\end{tabular}


A Figura 28 apresenta um gráfico que compara os valores estimados e reais para a variável T1, calculados pela RNA totalmente conectada com 4 neurônios na camada escondida. No gráfico da Figura 29 a mesma comparação é feita, mas para uma RNA otimizada, também com 4 neurônios na camada escondida. Nos dois gráficos, a curva azul é composta pelos valores reais enquanto a curva vermelha foi criada com os valores estimados pela RNA.

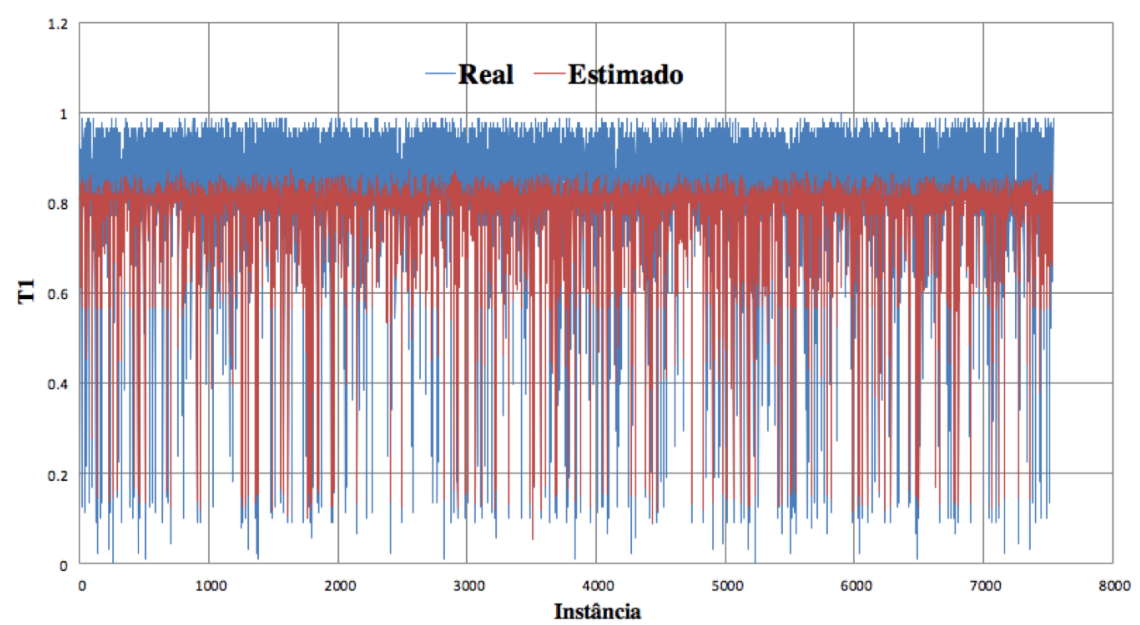

Figura 28 - Variável T1: saída desejada comparada com a saída obtida pela RNA totalmente conectada com 4 neurônios na camada escondida

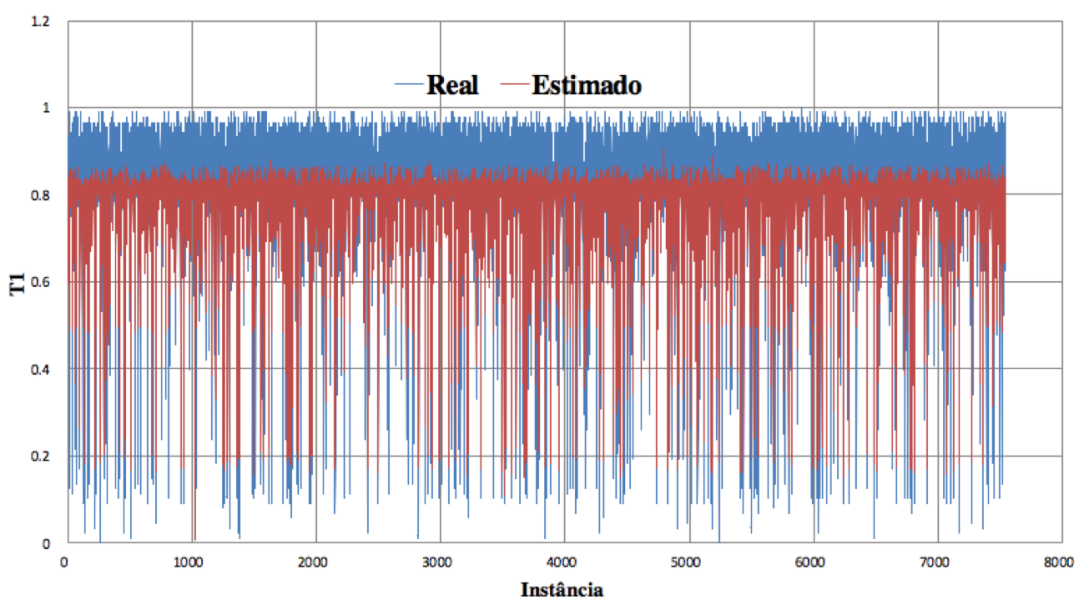

Figura 29 - Variável T1: saída desejada comparada com a saída obtida pela RNA otimizada com 4 neurônios na camada escondida 


\subsubsection{Testes com cinco neurônios na camada escondida}

A Figura 30 apresenta a rede neural sugerida pelo algoritmo OCFRN para estimar o valor da variável T1 a partir das variáveis N2, N3 e N4 - configuração com 5 neurônios na camada escondida. Dentre outras, algumas diferenças em relação à rede totalmente conectada podem ser destacadas nessa figura: na topologia sugerida, as entradas $A$ e $C$ estão conectadas a apenas um neurônio na camada escondida; há conexões entre neurônios da camada escondida; um dos neurônios da camada escondida não foi utilizado. A Tabela 6 compara o desempenho da topologia otimizada com o da topologia totalmente conectada.

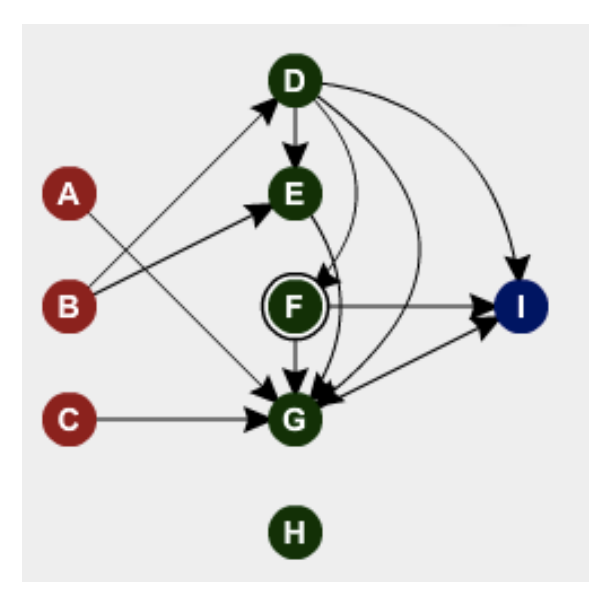

Figura 30 - Rede neural otimizada com as variáveis N2, N3, N4 e T1 (configuração com 5 neurônios na camada escondida)

A Figura 31 apresenta um gráfico que compara os valores estimados e reais para a variável T1, calculados pela RNA totalmente conectada com 5 neurônios na camada escondida. No gráfico da Figura 32 a mesma comparação é feita, mas para uma RNA otimizada, também com 5 neurônios na camada escondida. Nos dois gráficos, a curva azul é composta pelos valores reais enquanto a curva vermelha foi criada com os valores estimados pela RNA. 
Tabela 6 - Desempenho das RNA que estimam T1 com 5 neurônios na camada escondida

\begin{tabular}{|l|c|l|}
\hline & Totalmente conectada & Otimizada \\
\hline Coeficiente de correlação & 0,50 & 0,76 \\
\hline Erro absoluto médio & 0,10 & 0,07 \\
\hline Erro quadrático médio & 0,15 & 0,10 \\
\hline
\end{tabular}

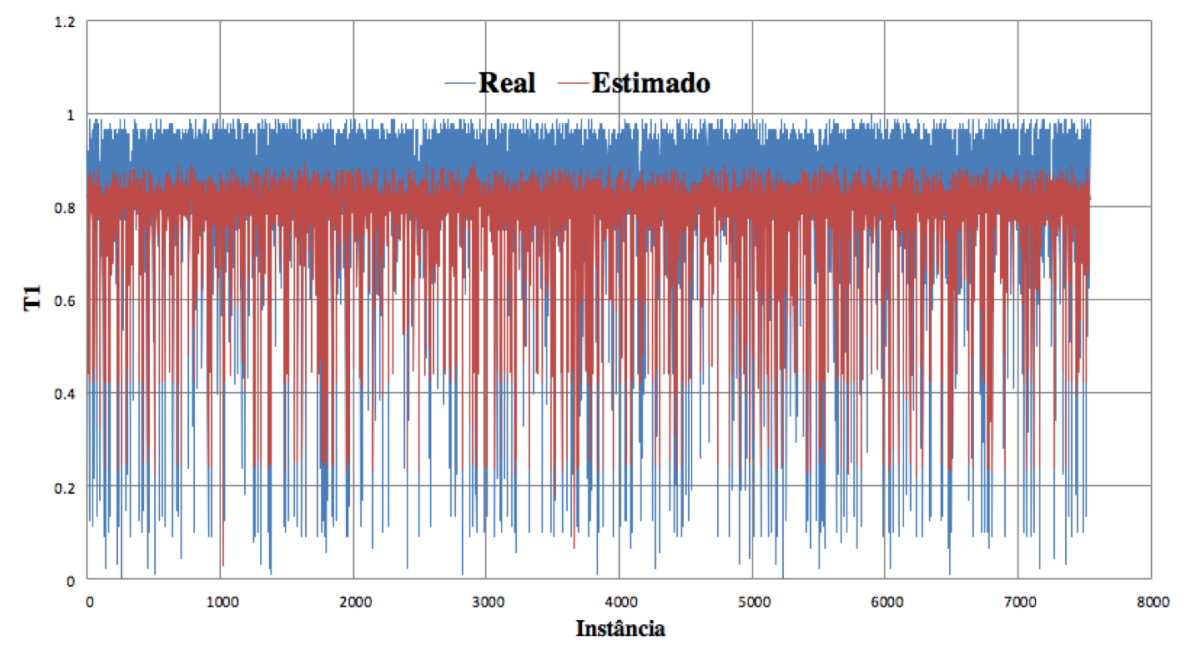

Figura 31 - Variável T1: saída desejada comparada com a saída obtida pela RNA totalmente conectada com 5 neurônios na camada escondida

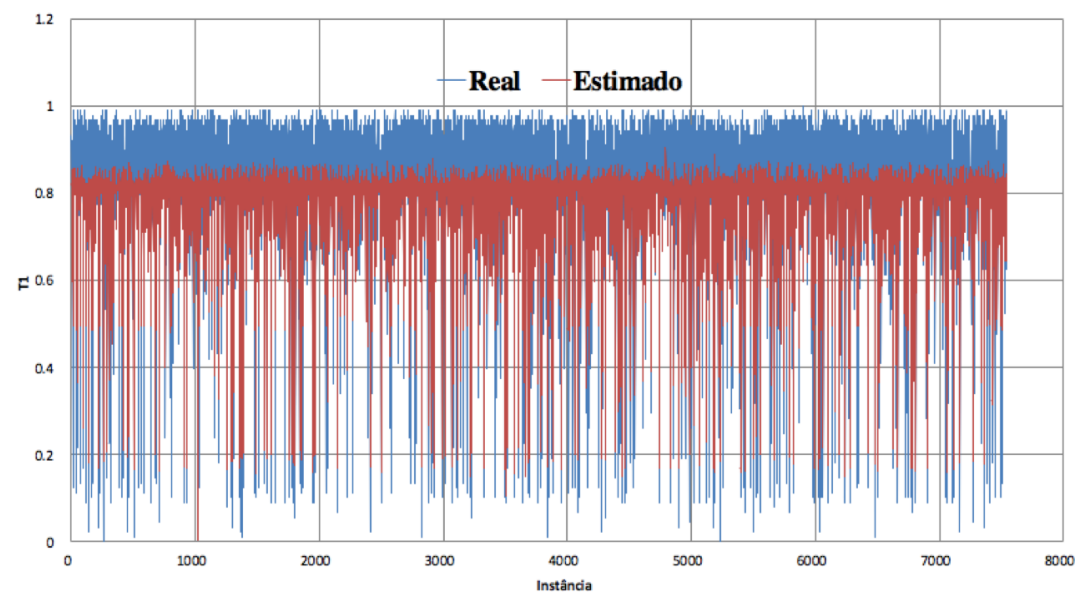

Figura 32 - Variável T1: saída desejada comparada com a saída obtida pela RNA otimizada com 5 neurônios na camada escondida 


\subsubsection{Testes com seis neurônios na camada escondida}

A Figura 33 apresenta a rede neural sugerida pelo algoritmo OCFRN para estimar o valor da variável T1 a partir das variáveis N2, N3 e N4 - configuração com 6 neurônios na camada escondida. Dentre outras, algumas diferenças em relação à rede totalmente conectada podem ser destacadas nessa figura: na topologia sugerida, a entrada $B$ está conectada a apenas um neurônio na camada escondida; há conexões entre neurônios da camada escondida; dois neurônios da camada escondida não foram utilizados pelo algoritmo OCFRN (ficaram desconectados dos demais). A Tabela 7 compara o desempenho da topologia otimizada com o da topologia totalmente conectada.

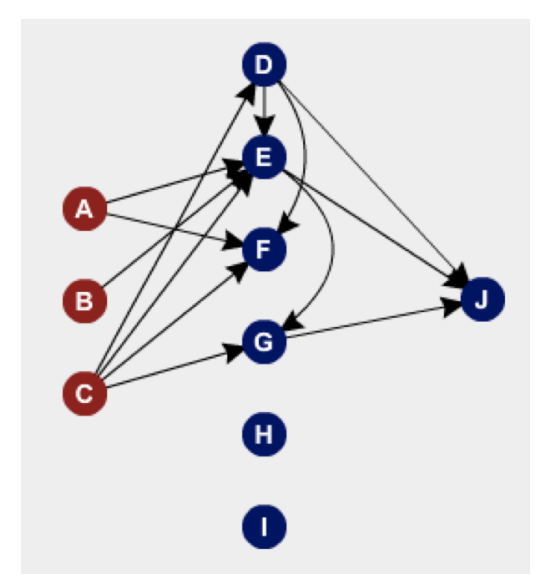

Figura 33 - Rede neural otimizada com as variáveis N2, N3, N4 e T1

(configuração com 6 neurônios na camada escondida)

A Figura 34 apresenta um gráfico que compara os valores estimados e reais para a variável T1, calculados pela RNA totalmente conectada com 6 neurônios na camada escondida. No gráfico da Figura 35 a mesma comparação é feita, mas para uma RNA otimizada, também com 6 neurônios na camada escondida. Nos dois gráficos, a curva azul é composta pelos valores reais enquanto a curva vermelha foi criada com os valores estimados pela RNA. 
Tabela 7 - Desempenho das RNA que estimam T1 com 6 neurônios na camada escondida

\begin{tabular}{|l|c|l|}
\hline & Totalmente conectada & Otimizada \\
\hline Coeficiente de correlação & 0,32 & 0,72 \\
\hline Erro absoluto médio & 0,10 & 0,08 \\
\hline Erro quadrático médio & 0,16 & 0,11 \\
\hline
\end{tabular}

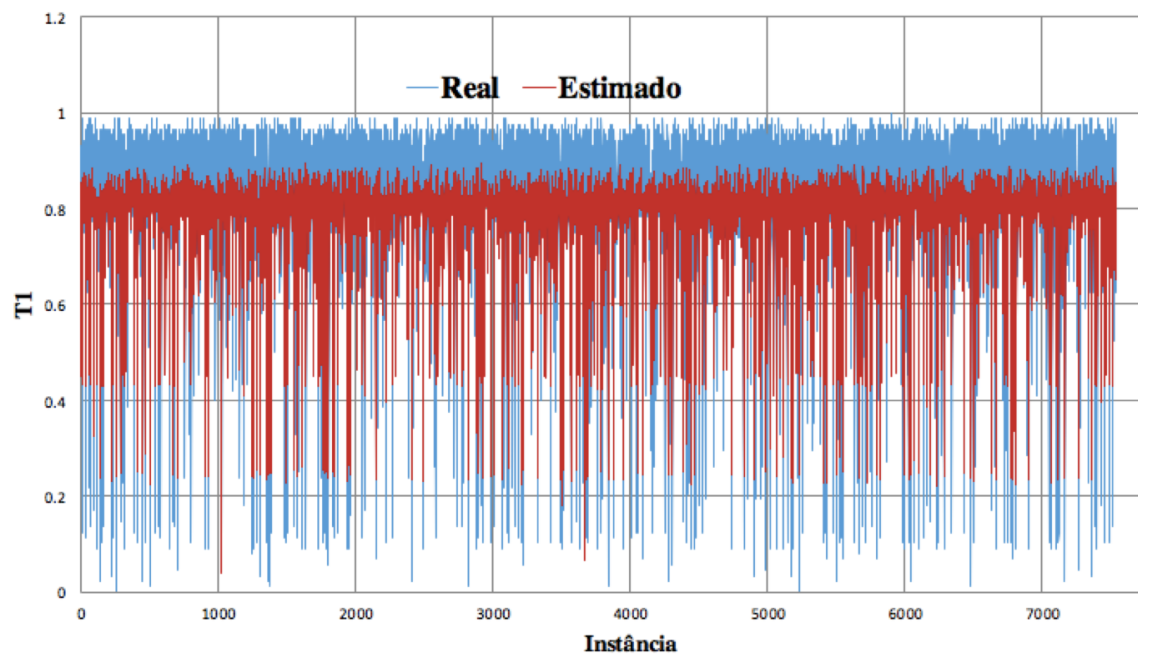

Figura 34 - Variável T1: saída desejada comparada com a saída obtida pela RNA totalmente conectada com 6 neurônios na camada escondida

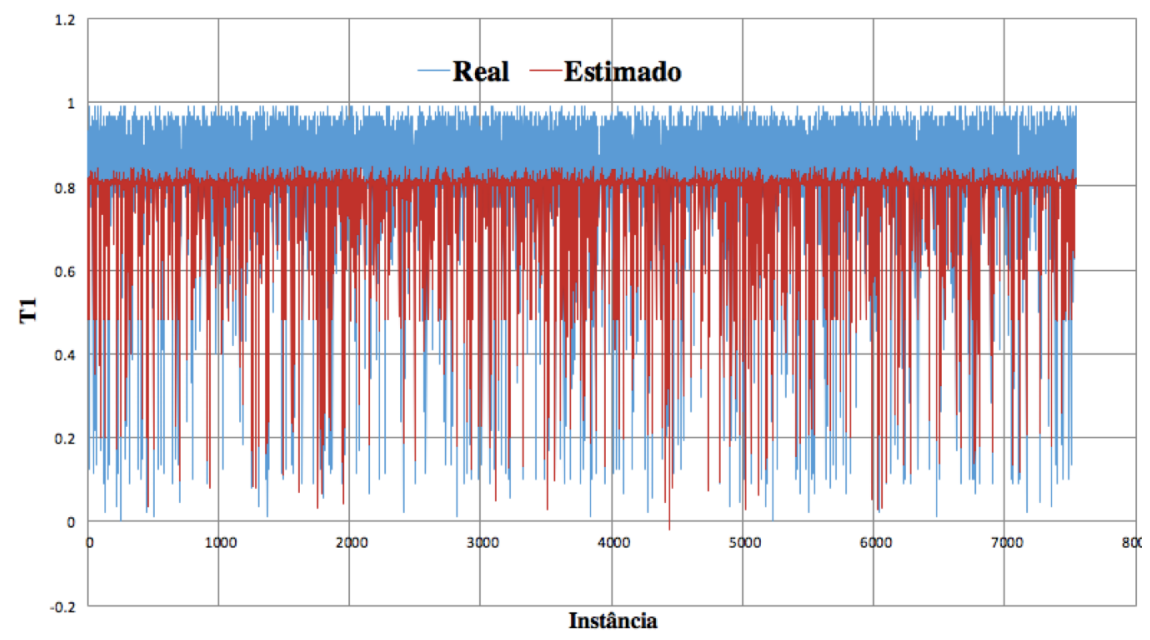

Figura 35 - Variável T1: saída desejada comparada com a saída obtida pela RNA otimizada com 6 neurônios na camada escondida 


\subsubsection{Discussão dos resultados}

Em todos os testes, o algoritmo OCFRN encontrou topologias para RNA capazes de estimar as saídas com menor erro quando comparados com as estimativas calculadas através de topologias totalmente conectadas. A maior diferença de desempenho foi obtida quando estimando T1 a partir de N2, N3 e N4, numa topologia com 6 neurônios na camada escondida. Neste caso, o coeficiente de correlação calculado ficou com valores 0,32 e 0,72 para as topologias totalmente conectada e otimizada, respectivamente.

Comparando todas RNA otimizadas que foram treinadas para estimar R1M3, o coeficiente de correlação ficou em 0,87, 0,87 e 0,88 para as configurações com quatro, cinco e seis neurônios na camada escondida, respectivamente. As topologias sugeridas com as 3 configurações mostram que no máximo 4 neurônios da camada escondida foram utilizados, o que sugere que este é o número ideal de neurônios para essa camada.

As RNA otimizadas para estimar T1 obtiveram como coeficiente de correlação os valores $0,75,0,76$ e 0,72 para as configurações com quatro, cinco e seis neurônios na camada escondida, respectivamente. As topologias resultantes nos testes com as 3 quantidades de neurônios na camada escondida também indicam que 4 é o número ideal de neurônios na camada escondida. Isso porque nos testes com 5 e 6 neurônios apenas 4 neurônios foram utilizados na camada escondida, os demais ficaram desconectados da rede.

Os resultados indicam que o desempenho de RNA com propagação para frente pode ser melhorado escolhendo-se as melhores conexões entre os neurônios ao invés de se utilizar uma topologia totalmente conectada. O algoritmo OCFRN foi capaz de encontrar topologias que apresentam, na tarefa de regressão, um desempenho melhor ou igual ao das redes totalmente conectadas.

As curvas de estimativa de R1M3 e T1 utilizando as redes neurais totalmente conectadas e as redes otimizadas indicam que, embora o desempenho das redes otimizadas seja melhor, visualmente não há muita diferença entre elas. Nos gráficos de estimativas de T1 o eixo das ordenadas ficou valores entre 0 e 1 porque os dados referentes a essa grandeza foram normalizados. Essa normalização também explica a grande diferença entre os erros (tanto o erro quadrático médio quanto o erro absoluto médio) dos testes com os dois conjuntos de dados. 


\section{CONCLUSÕES}

Este trabalho utiliza a técnica de Otimização por Colônia de Formigas (OCF) para otimizar topologias de Redes Neurais Artificiais (RNA). As RNA treinadas têm como finalidade monitorar variáveis de operação do reator IPEN IEA-R1. Um conjunto de dados fornecido pelo Sistema de Aquisição de Dados (SAD) foi utilizado para criar modelos matemáticos capazes de estimar o valor de variáveis importantes do sistema, como R1M3 (taxa de dose) e T1 (temperatura na superfície da piscina).

O algoritmo OCF foi utilizado para sugerir, dentre as possíveis combinações de conexões entre os neurônios de uma RNA, aquelas que melhoram o desempenho da rede em relação à topologia que conecta todos os nós entre camadas adjacentes. Para executar a busca por soluções, as formigas artificiais utilizam a técnica de retropropagação com parâmetros simplificados.

Os resultados obtidos indicam que o desempenho de redes neurais com propagação para frente pode ser melhorado escolhendo-se as melhores conexões entre os neurônios ao invés de se utilizar uma topologia totalmente conectada. Nos testes com 4, 5 e 6 neurônios na camada escondida, o algoritmo OCFRN foi capaz de encontrar topologias que apresentam um desempenho melhor na tarefa de estimar o valor das variáveis escolhidas. A metodologia utilizada incluiu o treinamento de RNA usando a técnica de validação cruzada com dez partições, o que permite gerar modelos onde o problema de sobreajustamento é minimizado. Embora o IEA-R1 seja um reator de pesquisas, acreditamos que os resultados obtidos possam ser utilizados para estimar valores de variáveis monitoradas em reatores de potência.

\subsection{Recomendações para trabalhos futuros}

- Expandir o algoritmo OCFRN para trabalhar com redes neurais artificiais com múltiplas camadas escondidas.

- Utilizar Otimização por Colônia de Formigas para otimizar os pesos iniciais, a taxa de aprendizado e o momentum, usados como parâmetros de treinamento de uma Rede Neural Artificial.

- Utilizar Otimização por Colônia de Formigas para otimizar, em topologias totalmente conectadas, o número de camadas escondidas numa RNA, bem como o número de neurônios em cada camada. 
- Utilizar Lógica Nebulosa para melhorar o desempenho da Otimização por Colônia de Formigas na tarefa de encontrar topologias otimizadas para Redes Neurais Artificiais.

- Usar algoritmos genéticos para escolher as melhores conexões entre os neurônios. 


\section{REFERÊNCIAS BIBLIOGRÁFICAS}

1 ARENY, R. P. Sensores y acondicionadores de señal - prácticas. Barcelona: Marcombo, 2004.

2 BUENO, E. I.; GONÇALVES, I. M. P. Estudo comparativo entre GMDH e redes neurais aplicados na monitoração de sensores. Revista do Instituto Federal de Educação, Ciência e Tecnologia de São Paulo, p. 182-189, 2010.

3 WILLSKY, A. S. A survey of design methods for failure detection in dynamic systems. Automatica, v. 12, p. 601-611, 1976.

4 BUENO, E. I. Utilização de redes neurais artificiais na monitoração e detecção de falhas em sensores do reator IEA-R1. 2006. Dissertação (Mestrado) - Universidade de São Paulo, São Paulo.

5 GARCÍA, E. A. Detectando fallas mediante redundancia analítica. Ingenierías, v. 4, p. $43,2001$.

6 CHOW, E. Y.; WILLSKY, A. S. Analytical redundancy and the design of robust failure detection systems. Automatic Control, v. 29, p. 603-614, 1984.

7 WANG, L.; NIU, Q.; FEI, M. A novel quantum ant colony optimization algorithm and its application to fault diagnosis. Transactions of the Institute of Measurement and Control, v. 30, p. 313-329, 2008.

8 MOEIN, S. Medical Diagnosis Using Artificial Neural Networks. Hershey: IGI Global, 2014.

9 RUSSEL, P.; NORVIG, S. Artificial Inteligence - a modern approach. Upper Saddle River: Prentice Hall Press, 2003.

$10 \mathrm{KOEHN}$, P. Combining genetic algorithms and neural networks: The encoding problem. 1994. Dissertação (Mestrado) - The University of Tennessee, Knoxville.

11 GINIDI, A. R.; KAMEL, A. M.; DORRAH, H. T. Development of new fuzzy logicbased ant colony optimization algorithm for combinatorial problems. Cairo: Cairo University, 2010. 
12 KUMAR, R. Theory of Automata, Languages \& Computation. New Delhi: Tata McGraw-Hill, 2010.

13 SORSA, T.; KOIVO, H.; KOIVISTO, H. Neural Networks in process fault diagnosis. IEEE Transactions on systems, Man and Cybernetics, v. 21, p. 815-825, 1991.

14 WIDODO, A.; YANG, B. Support vector machine in machine condition monitoring and fault diagnosis. Mechanical Systems and Signal Processing, p. 2560-2574, 2007.

15 YONGLI, Z.; LIMIN, H.; JINLING, L. Bayesian networks-based approach for power systems fault diagnosis. Power Delivery, IEEE Transactions on, p. 634-639, 2006.

16 CHEN, M. et al. Autonomic Computing - Failure diagnosis using decision trees. [S.1.]: Springer, 2004.

17 BISHOP, J. M.; BUSHNELL, M. J. Genetic Optimisation of Neural Network Architectures for Colour Recipe Prediction - Proceedings of the International Joint Conference on Neural Networks and Genetic Algorithms. Ljubljana: Innsbruck, 2011.

18 DORIGO, M.; GAMBARDELLA, L. M. Ant colonies for the travelling salesman problem. BioSystems, v. 43, p. 73-81, 1997.

19 GONÇALVES, I. M. P. Monitoração e diagnóstico para detecção de falhas de sensores utilizando a metodologia GMDH. 2005. Tese (Doutorado) - IPEN, São Paulo.

20 BASHIRI, M.; GERANMAYEH, A. F. Tuning the parameters of an artificial neural network using central composite design and genetic algorithm. Scientia Iranica, v. 18, p. $1600-1608,2011$.

21 SALAMA, K.; FREITAS, A. Learning Bayesian network classifiers using ant colony optimization - Swarm Intelligence, 2013.

22 SALAMA, K.; ABDELBAR, A. M. A novel ant colony algorithm for building neural network topologies - Swarm Intelligence. [S.1.]: Springer International Publishing, 2014.

23 BENNET, D. J.; THOMSON, J. R. The Elements of Nuclear Power. London: Longman Scientific \& Technical, 1989.

24 RELATÓRIO de Análise de Segurança do reator de pesquisas do IPEN IEA-R1(RAS). [S.1.]: Instituto de Pesquisas Energéticas e Nucleares. 
25 TANOMARU, N.; HIROMOTO, M. Y. C. Manual de Instalação e operação do SAD IEA-R1 No R22.10-3121-Ho-01/00. [S.1.]: [s.n.], 1998.

26 ROSSI, H. P. S. Utilização de Redes Neurais da Monitoração da Potência do Reator IEA-R1. 2001. Dissertação (Mestrado) - USP, São Paulo.

27 ARAÚJO, G. M. Normas regulamentadoras comentadas : legislação de segurança e saúde no trabalho. 8. ed. Rio de Janeiro: Gerenciamento Verde Editora, v. 2, 2014.

28 TAVARES NETO, R.; FERNANDES, R.; GODINHO FILHO, M. Otimização por colônia de formigas para o problema de sequenciamento de tarefas em uma única máquina com terceirização permitida. Gest. Prod., v. 20, p. 76-86, 2013.

29 VENDRAMIN, A. C. B. K. GrAnt - um protocolo de roteamento baseado em inteligência coletiva para redes tolerantes a atrasos. 2012. Tese (Doutorado) Universidade Tecnológica Federal do Paraná, Curitiba.

30 SANTOS, R. L. Uma aplicação de algoritmos de colônias de formigas em problemas de roteirização de veículos com janelas de tempo. 2006. Dissertação (Mestrado) Pontifícia Universidade Católica do Rio de Janeiro, Rio de Janeiro.

31 SILVA, R. M. A. Otimização Baseada em Colônia de Formigas Aplicada ao Problema da Cobertura de Conjuntos. 2003. Tese (Doutorado) - Universidade Federal de Pernambuco, Recife.

32 BALUZ, R. A. R. S. Uma aplicação de sistemas inteligentes híbridos ACO-Fuzzy para a otimização do desempenho em redes de sensores sem fio. 2013. Dissertação (Mestrado) - Universidade de Fortaleza, Fortaleza.

33 BORGES, M. E. Insetos Sociais como sistemas complexos. 2012. Dissertação (Mestrado) - Curitiba.

34 CECILIA, J. et al. Enhancing data parallelism for ant colony optimization on gpus. Journal of Parallel and Distributed Computing, v. 73, p. 42-51, 2013.

35 Angelo, J. S.; Augusto, D. A.; Barbosa, H. J. C. Ant Colony Optimization Techniques and Applications. Rijeka: InTech, 2013.

36 DORIGO, M.; COLORNI, A.; MANIEZZO, V. Positive feedback as a search-strategy. Milão: [s.n.], 1991. 
37 CASTILlO, O. et al. Dynamic Fuzzy Logic Parameter Tuning for ACO and Its Application in the Fuzzy Logic Control of an Autonomous Mobile Robot. International Journal of Advanced Robotic Systems, v. 10, 2013.

38 STUTZLE, T. et al. Parameter adaptation in ant colony optimization - In : Autonomous Search. Berlin: Springer, 2011. 191-215 p.

39 SWAMINATHAN, S. Rule induction using ant colony optimization for mixed variable attributes. 2006. Dissertação (Mestrado) - Texas Tech University, Lubbock.

40 AGUILAR, J. Revista de Matematica - Teoria y Aplicaciones, v. 12, p. 51-60, 2012.

41 TAVARES NETO, R. F.; GODINHO FILHO, M. Proposta de um framework para prototipagem de sistemas heurísticos multiagentes baseados em algorítmos de colônia de formigas. Pesquisa Operacional, p. 643-668, 2009.

42 JAIN, A. K. Artificial neural networks - a tutorial. Computer, p. 31-44, 1996.

43 JAIN, S. K.; SINGH, V. P. Water Resources Systems Planning and Management. Baton Rouge: Elsevier, 2003.

44 Shanmuganathan, S.; SAMARASINGHE, S. Artificial Neural Network Modelling. Basel: Springer, 2016.

45 WITTEN, I. H.; FRANK, E.; HALL, M. A. Data Mining - Practical machine learning tools and techniques. San Francisco: Morgan Kaufmann, 2005.

46 MITCHEL, T. M. Machine learning. [S.1.]: McGraw-Hill, 1997.

47 KOHAVI, R. A study of cross-validation and bootstrap for accuracy estimation and model selection. [S.1.]: [s.n.], v. 14, 1995. 